\title{
A Medieval Puzzle. The 'Architecture' of the Page in Manuscripts and Incunabula of the Codex Justinianus
}

The image most often associated with a medieval law manuscript is that of a teacher sitting at a raised desk in a university classroom as he reads and comments on a normative text to a group of students who attentively follow their master's disquisition, all the while making notes on what is being said in the margins of their manuscripts.

This association is fully justified by the fact that juridical codices are, in many respects, products of $12^{\text {th }}$ to $14^{\text {th }}$ century university culture. Indeed, such volumes reflect the scientific principles and criteria used to organise the new legal doctrine; in addition, they provide evidence of the reproduction and dissemination mechanisms that were fostered and overseen by the major Studia in the cities where the universities were situated.

Viewed in this way, all medieval law books used for professional and educational purposes constitute, either directly or indirectly, important and valuable testimony of the academic world's scientific activity. Specific planning and execution methods mean that such codices represent a very well-defined book typology with peculiar characteristics, thus making them an interesting and thoughtprovoking object of study.

The above preamble is necessary in order to introduce the particular 'terrain' that the present research aims to cover and the objectives it seeks to fulfil. Our goal is to analyse the structure of the page in a juridical codex by examining the criteria that dictated the organisation and structuring of all its components-both written

Translated from the Italian into English by Mark Livesey. Original published as Devoti, Luciana (1999), 'Un rompicapo medievale. L'architettura della pagina nei manoscritti e negli incunaboli del Codex di Giustiniano', in Busonero, Paola / Casagrande Mazzoli, Maria Antonietta / Devoti, Luciana / Ornato, Ezio, La fabbrica del codice. Materiali per la storia del libro nel tardo medioevo, Roma: Viella (I libri di Viella, 14), 143-206.

This work is the outcome of a specialisation thesis undertaken at the University of Cassino in 1995. I would like to thank Marco Palma and Ezio Ornato for consistently following my progress, and for making helpful suggestions concerning the study of the medieval book from an alternative and innovative standpoint. 
and non-written-and the ways in which the space allocated to accommodate the text was exploited and utilised.

Interest in the 'architecture' of the page and the arrangement of the elements that determine its design is inspired by the striking homogeneity and uniformity which characterise, when seen from this perspective, a juridical book. Text and commentary are arranged according to schemes that were almost identical in all centres of production during the period stretching from the $8^{\text {th }}$ to $15^{\text {th }}$ centuries, an observation which is true of both manuscripts and printed books. This makes it both feasible and justifiable to carry out an investigation on the strategies employed by the various artisans concerned when they shaped and organised a predetermined quantity of text in relation to the page space available to them. With this goal in mind, the question has been posed as to whether or not the uniformity which is so typical of the pages of legal codices is the result of specific strategies and choices. Stated more precisely, our aim has been to discover whether, in order to synchronise the text associated with the commentary, solutions of a functional kind prevailed that were aimed at ensuring that related passages remained in proximity to each other; or if, conversely, greater stress was placed on aesthetic considerations, with the objective of creating a visually homogeneous effect. Finally, we have investigated how, and to what extent, within the bounds of certain mechanisms, written and non-written areas of the page were worked on.

The present investigation takes advantage of quantitative analysis methodologies which have already been widely experimented with in various fields of historical research, not least that of the book. ${ }^{1}$ However, even if such an 'experimental' approach is not exactly ground-breaking with respect to codicology, it does appear to be so as far as law books are concerned, at least from the standpoint of the issues that will be addressed in the present contribution. The association of a book typology with the specific context in which it was planned and realised, and within which it found its intended application and ultimate purpose, has long been the source of inspiration behind these studies. ${ }^{2}$ Likewise, the mechanisms involved in the con-

1 The complexity of the motives and aims which lie at the root of this methodology have been amply addressed by Bozzolo / Ornato 1982; Bozzolo / Ornato 1986; Ornato 1991.

2 A similar premise is the basis of numerous contributions aimed at the analysis of this book typology. Such contributions are ultimately inspired by the direction taken by Jean Destrez in his seminal work La pecia (Destrez 1935). In his book, the author focuses attention on a series of issues and new aspects (previously disregarded) vis-à-vis the university manuscript in the four main centres of Paris, Bologna, Oxford and Naples (paying particular attention to the first two centres). In addition, he addresses themes relating to tradition and textual criticism. Destrez also shows an interest in the elements that characterise the architecture and construction of the page and the techniques that were predominantly used in the manufacture of manuscripts, albeit always from the standpoint of 
struction of the page and the relationship that exists between its component parts do not constitute a novelty and, indeed, are often referred to in manuals and the numerous contributions dedicated to the multifarious aspects of manuscript and printed books. All the same, an in-depth examination of such issues within this particular book typology has not been attempted before now. ${ }^{3}$

In order to be able to provide answers to the questions posed above, in the first place it was necessary to establish the boundaries of the research, both from the qualitative and quantitative standpoint. Indeed, the goal set was that of building a suitable and sufficiently representative corpus of witnesses so as to be able to furnish all the information necessary to carry out the investigation. With this object in mind, attention was focused on a sample of manuscripts dating from the $13^{\text {th }}$ to $14^{\text {th }}$ centuries and incunabula dating from last quarter of the $15^{\text {th }}$ century, all containing the Codex Justinianus with the 'ordinary gloss' (Glossa ordinaria).

drawing a comparison between the different editorial policies practiced by the various universities, in relation to an institution 'qui correspond à cet état des choses nouveau, créé par l'évolution sociale, institution qui arriva à sa pleine perfection dès le milieu du XIII ${ }^{\mathrm{e}}$ siècle, e qui durera jusqu'à la mise en circulation des premiers livres imprimés: c'est la pecia'. Destrez's treatise represented an important starting point for subsequent research, most of which focused (above all) on themes relating to the production and marketing of the university codex. New discoveries of a documentary nature, together with a deepening, and in some cases critical revision of the sources already known by Destrez, have contributed to enriching and widening the breadth of such research. An important moment for taking stock of the state of affairs regarding these studies occurred almost fifty years after the publication of La pecia at a symposium titled La production du livre universitaire, held in 1983 at the Collegio di San Bonaventura at Grottaferrata (Bataillon et al. [eds] 1988). In this instance, too, the attention paid to university books of (not solely) legal content was essentially inspired by the always complicated question vis-à-vis reproduction mechanisms and the possibility of reconstructing operational criteria based on the available evidence. A great deal of interest has also developed around production issues in relation to the juridical incunabulum; the most recent contributions on this topic are Coq / Ornato 1988, in which production of legal incunabula in the principal Italian, French and German markets is analysed, based on 1,200 editions dating from 1460 to 1500 and belonging to three categories, namely Roman law, canon law and judicial practice manuals; and Thilo 1984, in which an investigation of the history of law book printing is carried out with respect to the Germanic area (a list of texts from the Corpus Iuris Civilis published between 1400 and 1800 is also provided).

3 Certain themes in relation to the structure of law books have been addressed, albeit only in part and in a predominantly descriptive way, in two contributions by Jacqueline Rambaud, in which the author considers some important pieces of evidence from the Decretum Gratiani (Rambaud 1990) and the Decretales (Rambaud 1990a). She also illustrates the arrangement of the text and its glosses with particular regard to the use of decoration within the various subdivisions of the works. For an overview of the ways in which glosses and commentary developed within various literary genres, see Holtz 1995. Concerning the codification of various systems for the layout of pages with annotations, see Powitz 1979 (in particular, 84-85, where framework No. 6, which corresponds to the one in our sample, is described). 


\section{Text and apparatus}

The term 'law book' is rather vague and is used to refer to a literary genre that encompasses a vast range of works. In the Middle Ages, the two great categories of law-canon and civil-included cornerstone regulatory texts along with a series of treatises of various kinds designed to complement them: lecturae, summae, quaestiones, repetitiones, etc. For the purposes of the present investigation, it was considered best to focus our attention on just one of the two great categories, namely civil law, and in turn on one of its basic sub-divisions, namely the Codex. The Codex Justinianus represents a section of the Corpus Iuris Civilis ${ }^{4}$ and was widely disseminated and particularly well known within universities and beyond their precincts. It was therefore a heavily used text both for teaching purposes and in the course of legal practice. A series of documents relating to the book trade in Bologna between the second half of the $13^{\text {th }}$ century and first three decades of the $14^{\text {th }}$ (preserved in the Ufficio dei Memoriali fund of the State Archives of Bologna) ${ }^{5}$ furnishes much evidence regarding the production and circulation of the Codex. Roughly $57 \%$ of sale and purchase contracts and writings relating to works in the

4 According to tradition, Justinian's Corpus Iuris Civilis was divided into five volumes. The first three comprised the books of the Digesta, traditionally divided into the Digestum Vetus (books 1-24.2), the Digestum Infortiatum, or simply Infortiatum (books 24.3-38.17), and the Digestum Novum (books 39.1-50.17). In turn, the Infortiatum was divided into two sections; the second (35.2-38.17) was indicated by the words Tres Partes, and began with Law 82 of book 35.2. The fourth book was composed of the first nine books of the Codex. The fifth contained all the remaining texts and was known as the Volumen; these comprised the Institutiones, the Novellae according to the version in the Authenticum collection (called for this reason the Authenticae or Authenticum) divided into nine collationes, the Tres libri, or the last three books of the Codex, and the Libri Feudorum and a few imperial laws added at a later date as a tenth collatio. Justinan's legislation, which spread across Italy in 554 with the Pragmatica Sanctio, dissipated in the Early Middle Ages, to the extent that many collections were broken up, and some disappeared entirely. It was during the $11^{\text {th }}$ century, in all likelihood on the initiative of some jurists, that Justinian's law was rediscovered. The first texts to reappear were the Institutiones and the books of the Codex. The task of recuperating and organising the other texts based on the original arrangements then fell to Irnerio and his milieu, and it would be Irnerio himself, according the testimony of Odofredus, who began to teach and write glosses to better illustrate Roman laws. On the disappearance and rediscovery of the Justinian's texts during the Middle Ages, see Astuti 1968a, 57-73, 297-338; Calasso 1954, and, more generally, Bellomo 1988, 7-33.

5 Published in Chartularium 1909-1988 and in Orlandelli 1959. 
Corpus Iuris Civilis concern the text of the Codex, which also addresses other types of transaction, such as pledge, loan, and transportation contracts. ${ }^{6}$

The planning of curricula in law schools varied according to the universities and faculties concerned. In any event, the teaching of the Codex was considered to be of fundamental importance and was imparted by the masters (doctores) during the courses called ordinarii, which generally took place in the morning. ${ }^{7} \mathrm{~A}$ collection of norms relating to the university statutes of Bologna of 1252 (the oldest that have come down to us) illustrate the teaching system which was based on the puncta, that is to say the times and ways in which the juridical texts were to be read. In the case of the Codex, two lesson cycles were envisaged. The first was divided into seven parts with each part lasting fourteen days; the second cycle was divided into nine parts which each lasted for twelve days. The entire programme added up to a grand total of 206 days, during which all nine of the volumes would be read. ${ }^{8}$

The lectura represents the original and enduring form of university teaching. Essentially, it is born from an awareness that it is only on the basis of authoritative readings of texts that the student's mind can arrive at the truth. Legere becomes a synonym for 'to teach' and 'to study', and it is only a work, or an accredited interpretation-and therefore one which is officially recognised and guaranteed-which is valid and can be considered an indisputable point of departure. Reading 'devient ainsi une pratique que l'on peut organiser, determiner à l'avance; elle se donnne pour but la preparation culturelle et l'activité didactique et scientifique du nouvel intellectuel professionel, qu'il soit laïc ou religieux: professeur, juriste, médecin, théologien, notaire'. ${ }^{9}$ A method of this kind, which is very widely used in all fields of knowledge, becomes all the more important in the legal context, where the rediscovery of the Justinian texts and the need to endow the law with certainty does not arise purely from an intellectual interest, but instead represents an indispensable premise for a society which is in the process of organising itself into new political and institutional entities that differ from those of the past.

6 For the last mentioned, in addition to the Chartularium and Orlandelli's study, see, in particular, Stelling Michaud 1963. For sales, purchase and writing contracts, see also Devoti 1994, and Devoti / Tristano 1998.

7 In addition to the Codex, the Digestum Vitus was included in the ordinarii courses. The other texts in the Corpus Iuris Civilis were instead read during the post meridiem lessons (the extraordinariae), held by the Bachelors of Law.

8 Maffei 1975, 94-96.

9 Petrucci 1984, 610; see also Saenger 1982, 391-393. 
From the earliest days of university teaching, the reading of Justinian works envisaged both the analysis and the elucidation of individual laws and their glosses. For the most part, this consisted in quoting the norms relating to the subject addressed by the passage being examined. The majority of cases concerned analogous or contrary laws (loci similes et contrarii), all of which could be found within the same Justinian compilation. Quotations from these laws were translated into brief notes and observations which were then inscribed in the margins of the manuscripts. These preliminary glosses constituted a starting point and provided a network of references to parallel texts to be expanded upon and examined in more depth. Thus, once 'the fragment to extrapolate from had been identified it was copied out and appended as a gloss to the text to be elucidated, like a new interpretative tool which served to clarify the text's meaning and develop its content' ${ }^{10}$ However, with the passage of time, analysis of the law became more complex, hence from a simple reutilisation of the material extracted (or to be extracted) from the Corpus Iuris, a shift was made to a more detailed exegesis, which at first consisted in the illustration of the casus (i.e. the legal case), and subsequently in the explication of a full series of problematical aspects relating to the various interpretations.

Thus, the book became an indispensable tool for the production of scientific elaborations and for 'fixing' the same for future reference: 'on lit pour écrire... on lit et on écrit tout ensemble quand on commente et quand on annote; on écrit en lisant quand on compose, car tout texte est-nécessairement-fondé sur l'auctoritas' des prédécesseurs et sur l'usage permanent de la citation' . ${ }^{11}$

The glosses were associated to the main text by means of a reference symbol. In the earliest times a number of different symbols were employed, the paragraph sign (§) being particularly widespread (it was also used to indicate the addition of an individual gloss). Later on, various letters of the alphabet were used. In civil law manuscripts the reference symbol was followed by the incipit of the passage concerned.

Gero Dolezalek has shown that glossed juridical codices ${ }^{12}$ existed from the beginning of the $12^{\text {th }}$ century. However, such material was not yet fully developedi.e. it consisted of 'in progress' annotations'-even if it was not of a sporadic and merely occasional nature. In fact, it was the product and testimony of exegeses carried out in the scholae of the jurists. ${ }^{13}$ These early glossed manuscripts proba-

\footnotetext{
10 Bellomo 1988, 67.

11 Petrucci 1984, 610.

12 Dolezalek 1989, 205.

13 Dolezalek 1994.
} 
bly constituted the Libri magistrorum ${ }^{14}$-that is to say the volumes which belonged to school principals-to which the masters added their glosses or those of other jurists, which they then used during the lectures they delivered. With the passage of time, new evidence of the progress made during the scientific study of legal matters was added to or replaced earlier annotations. For this reason, manuscripts of the $12^{\text {th }}$ century, which can be traced back to one and the same 'archetype', or to one and the same school, often exhibit glosses that are similar but not identical. Thus, in order to lay claim to authorship and differentiate their glosses from earlier ones, the jurists began to add their initials (e.g. y[rnerius], b[ulgarus], $\mathrm{m}$ [artinus], r[ogerius] etc.), ${ }^{15}$ although these were frequently insufficient to maintain and ensure independent circulation. In fact, many manuscripts were erased in order to make way for new additiones. Others were transcribed, but during this process many initials were either intentionally or accidently rubbed out, perhaps because they were hidden between the original glosses and those which were added at a later date. ${ }^{16}$ Consequently, it is difficult to identify and recognise in the oldest manuscripts consistent sets of glosses, even if it is precisely at this moment in time that the notion of a 'layer' begins to assume relevance, understood to 'refer to the shared unitary tradition of a living text [...] identifiable by its actual circulation'. ${ }^{17}$

The decisive phase that immediately followed consisted in the merging of such agglomerations of glosses into a single, crystallised structure, which equates to the critical apparatus. In this structure the glosses were arranged and unified into a fixed order, thereby becoming identifiable and reproducible as the personal and autonomous work of the jurist who selected them. ${ }^{18}$ It is here that 'the historiographic notion of a "layer", as a group of glosses characterised in an agreed upon way, can converge with the historiographic notion of an "apparatus"; [...] in the historiographic "layer" a group of glosses, which can also have historical substance as an "apparatus", is evaluated for its structure. One must therefore say that each apparatus is also a layer, but that each layer is not necessarily an appa-

14 Dolezalek 1985, 42.

15 Sella 1932 and Sella 1935; Speciale 1994, Appendix C.

16 Dolezalek 1994, 248-241.

17 Caprioli 1981, 417; on the analysis of indications of the use of the glossed manuscripts contained in the Codex, see Speciale 1994.

18 On the one hand the spread of ordinary apparatuses indicated the high scientific level achieved by the Bolognese law schools, whilst on the other it represented, for university teaching, a remarkable combination of economic and ideological interests, thanks to the care and control exerted over the production and dissemination of texts destined to be used for educational purposes. 
ratus [...]. It can be said that henceforth the original structure of the group of glosses remained "uncontaminated", but not the way in which it circulated, since it no longer represented an "open" text, but instead a "closed" one'. 19

With respect to civil legal texts, the authors of the first standardised gloss apparatuses were Ugolinus and Azzo, even if the entire process of gathering, selecting and re-ordering the annotations that had accumulated from the time of Irnerius was only completed by Accursius in the first half of the $13^{\text {th }}$ century. ${ }^{20}$ The Accursian apparatus is at one and the same time a work of exegesis and compilation; in fact, the author did not limit himself to simply assembling the pre-existing material; ${ }^{21}$ he also subjected it to revision and elaboration-in both form and substance-in the light of the principles, definitions and classifications which by this time had become part of the scientific patrimony of the Bolognese schools of law. However, identification of pre-Accursian material within the Magna Glossa remains highly problematical, since the contributions of previous jurists who kept their initials intact are very few, whereas as a rule all the glosses present as having been realised by Accursius and frequently bear his initials ( $a c$. or $a c c$.), even when they are in fact the work of other authors. ${ }^{22}$

The term apparatus first began to be applied in the $12^{\text {th }}$ century and, despite being used to mean slightly different things, for a long time largely kept its generic meaning as 'a group of glosses intended for educational use'. ${ }^{23}$ Starting in the $13^{\text {th }}$ century, such groups of glosses came to be regarded as complete works of a compilatory nature that were produced with an instructional objective in mind, and whose nature essentially lies in the fact that they are strictly linked to the interpreted material, since the individual glosses normally refer to a specific lemma in the text. A wider and more generic definition saw the apparatus regarded as a group of glosses distributed in a certain way along the margins of the manu-

19 Caprioli 1981, 418-419.

20 Astuti's essays in Astuti 1968 are of fundamental importance, as are those of Soetermeer in Soetermeer 1989.

21 It has been calculated that the glosses produced by Accursius number amount to 96,940, of which 17,814 are for the Codex. See Kantorowicz 1929, 43.

22 Accursius developed the Magna Gloss a during the first forty years of the $13^{\text {th }}$ century. However, the question concerning the genesis and chronological succession of the apparatus remains unanswered. Based on an investigation carried out on a few manuscripts from the libri ordinarii, the Codex and the Digestum Vetus (containing various critiques of the glossa accursiana), Soetermeer suggests the decade spanning 1220-1230 for the publication of the apparatus for the Digesto Vecchio, and the period stretching between 1227 and 1234 for the Codex's apparatus (Soetermeer 1989, 2879 and 2892).

23 Colli 1990, 232-233. 
scripts so as to form a sort of continuous 'scaffolding', obtained by modelling the commentary in the form of a frame around the text. ${ }^{24}$

This characteristic-more physical than interpretive-reinstates to the term 'gloss' the exegetical function which traditionally was the preserve of jurists. Indeed, according to the jurists' lexicon, a gloss is a work of any kind which serves to provide an interpretation of the text, irrespective of its position on the page. ${ }^{25}$ The distinction between interlinear and marginal texts is therefore purely materi$\mathrm{al}^{26}$ and depends on the size of the support and the length of the commentary. Only when the latter has become sufficiently long so as to make it necessary to position it on the page according to certain rules and graphic devices can one speak of an apparatus or gloss apparatus.

\section{The law book}

The law book represents a rather peculiar and well-defined product, both from a structural perspective and in relation to its use, and the purpose it was intended to fulfil.

An indispensable work and study tool, the law book was shaped according to the needs of a culturally homogeneous and erudite readership composed of professionals, teachers and students, representing a category of technical intellectuals ${ }^{27}$ who were the leading actors in the rebirth of legal studies which emerged between the $12^{\text {th }}$ and $13^{\text {th }}$ centuries.

Such books have a distinctive appearance which is related to the educational criteria of the time: they were books to be placed on book rests ('libri da banco'), ${ }^{28}$ generally of large format, with the text arranged in two columns positioned towards the centre of the page so as leave space for ample margins to accommodate commentary written in a small hand, in accordance with a functional hierarchy which 'permet de differéncier l'essentiel de l'accessoire, le général du particulier' ${ }^{29}$ A structured system of references and pointers made it easy to link passages in the main text to the annota-

24 In this connection, the 'hypertextual' aspect of the Accursian apparatus has been highlighted-an ante litteram hypertext which is 'characterised by its fragmentary and non-linear nature, and for the inseparable connection, including on the physical level, between glossae and the legal text' (Speciale 1994, 36-37).

25 Colli 1990, 233.

26 Fransen 1982, 134.

27 This is Petrucci's definition, Petrucci 1983, 499.

28 Petrucci 1969, 298.

29 Ornato 1994, 10. 
tions, and both were positioned in such a way so as to be able to readily identify individual parts of the discourse thanks to the use of upper-case characters, penflourished initials in red and blue ink, sectioning of the text, and the paragraph sign (§), devices which also facilitated rapid consultation and memorisation. The impression of uniformity created by the Gothic script (typical of scholastic works), the use of a precise vocabulary and the adoption of a rather extensive system of abbreviations, which made it possible for an expert reader to complete the text 'in his head', all favoured the reading process. ${ }^{30}$

The uniformity of the product is also reflected in the ways in which it was executed and the manufacturing techniques employed; these were based on the pecia mechanism, a system upon which the new university publishing output was founded. The official models of the texts destined for teaching purposes-the exemplaria-were deposited at the workshops of the stationarii libonum and peciarum and were rented out as loose quires-the peciae, that is-at fixed rates, so as to permit rapid and simultaneous reproduction of the individual works. ${ }^{31}$ The copying process represented just one of various operations necessary for the manufacture of a book, albeit the most time consuming and costly one. ${ }^{32}$ In fact, the new techniques resulted in a clear division of the various work phases, based on the specific skills required of the workers, such as papermakers, pergamenarii (parchment makers), illuminators and rubicators, who, despite working in separate places, had a common connection with the book producing entrepreneur: the stationer, that is.

This model of the codex, which emerged in the university context between the $12^{\text {th }}$ and $13^{\text {th }}$ centuries, endured in the same environment for the entire $15^{\text {th }}$ century and was also reproduced in incunabula, which imitated their structure, format, layout, text arrangement, system of references, script, ${ }^{33}$ and the hierarchy decorative devices.

30 The structure of the reasoning had to be reflected in the structure of the book, based on the 'architecture' of the page, which corresponded not only to practical criteria, but was also a reflection of the new principles according to which human knowledge was defined and analysed itself, since 'the opportunity for further developments in the presentation of texts came as a result of the drive to reorganise inherited material in a new, systematic way, to make auctoritates not only accessible, but accessible in terms of new ways of thinking' (Parkes 1976, 117).

31 On the production mechanisms of the university book, only roughly outlined here, there exists an ample and detailed body of literature. The interested reader can refer to several fundamental works, including: Destrez 1935; Fink-Errera 1983; Pollard 1978; Bataillon et al. (eds) 1988; Soetermeer 1990 (now available in an Italian version, revised and expanded by the author, Soetermeer 1997); and Weeijers 1987.

32 Devoti 1994.

33 In fact, the use of Gothic characters turns out to be a distinguishing feature of the legal incunabulum (see Bozzolo et al. 1984, 212). 
The aforesaid continuity, as part of a radical transformation of book production techniques, is a commonly accepted precept: at first glance there exists, in effect, a great deal of affinity between the pages of a $15^{\text {th }}$-century law incunabulum and those of a manuscript volume containing precisely the same text. However, one has to ask oneself whether, and how, the inevitable and actual changes which resulted from the shift from a manuscript production system to printing had an impact on certain mechanisms used to adjust the text to the glosses; and whether the way in which the two text masses were arranged, with respect to the links that unite them, answers to the same functional and aesthetic needs, and if, as a result, the criteria applied for the exploitation and utilisation of the written area changed. Finally, with respect to proportions and regularity, one has to pose the following question: to which basic principles did all the written and non-written elements of a manuscript page and those of a printed volume conform ? $^{34}$

More than once in the past, the book production system based on the pecia mechanism has been defined as industrial ${ }^{35}$-albeit in a primitive way. The exemplaria of the text and gloss circulated separately and as loose quires. This ensured the simultaneous reproduction of multiple copies of one and the same text, since a scribe would rent one pecia at a time, thereby making it possible for the other scribes to work from the remaining 'pieces'. Whether the writing of the text and apparatus were executed simultaneously, or alternatively carried out at different times, the serial reproduction process, articulated by the 'rhythms' created by the pecia, should not, in theory, have altered the manual copying operation, which generally conformed to the natural sequence of the writing and the reading. However, a few exceptions were possible, when, for example, gaps in the rental or transcription of the quires occurred with respect to their position in the exemplar, a circumstance which would have constrained the scribe to align the 'composition' of the text according to the material unit upon which he was working, which did not necessary coincide with that of the circulating model. ${ }^{36}$

34 The dynamic of the relationship between the manuscript volume and the printed book, and between continuity and innovation, has been thoroughly addressed by Ornato 1985, and Ornato 1994, 18-31; see also Bozzolo et al. 1987, 121-133, concerning the mise en page of manuscripts and incunabula in Latin and French produced in France in the $15^{\text {th }}$ century.

35 One is not entirely in agreement with the use of this term, since it envisages a series of factors, such as the relationship between capital investment and productivity levels, which in reality are characteristic only of the printed book.

36 A pecia is in fact equivalent to half a quaternus, whilst in Italy, for example, the prevailing quire configuration in law books was the quinion (see Busonero 1999, 74-75 [in this volume, 205-307]). 
An eventuality that could sometimes occur in a manuscript-the non-sequential execution of pages-becomes the rule in the printed book, at least from about 1473 onwards, when the introduction of the double-page press made it possible to print two or more pages adjacent to each other on one sheet. ${ }^{37}$ This procedure, if on the one hand favoured printing productivity, on the other made typographic composition more difficult, thanks to an increase in problems arising with respect to the calibration of the text mass within the quires. ${ }^{38}$ The mechanisms used for the segmentation and arrangement of a written message naturally require the calculation of other factors, such as the size of the volume, the amount of the support to be utilised, and the division of the latter into constituent parts for the realisation of the work. The surface of the support must then be made ready to accommodate the text by delimiting spaces which are then subdivided into a certain number of lines, based on the number, size and type of characters and graphic devices to be employed.

The clear definition and management of all the aforementioned procedures represent essential steps, both in the preparation of manuscripts and of printed books, even if the rules that govern their combination and execution can differ.

It will therefore be interesting to investigate whether and how the choices and solutions adopted in the two different production contexts diverge or coincide in relation to the phenomena that we aim to address, and for which, as far as possible, we shall also try to provide an interpretation.

\section{The corpus of manuscripts and incunabula}

Given that one of the goals of this research was to analyse the text/gloss relationship based on the different ways employed to adapt one to the other on the page, the main criterion employed for selecting manuscript and printed books was the presence of an uninterrupted apparatus of glosses: in other words, an 'oeuvre litterairement achevée due à un auteur, connu o non, et qui forme un tout [...], un ensemble voulu et conçu comme tel, qui est recopié pour lui-même'. ${ }^{39}$ In fact, many manuscripts, despite being constructed in comformity with the classical canon-which is to say with the legal text positioned in the centre of the page and surrounded by generous margins intended to accommodate the commentary-contain occasional

37 Febvre / Martin 1985, 71; Coq / Ornato 1987, 92.

38 Concerning the numerous issues relating to the introduction of this new technique and the working practices adopted by $15^{\text {th }}$-century printers, see Ornato 1994, 20-21 and 28-29; and Coq / Ornato 1987, 90-93.

39 Fransen 1982, 137. 
or sporadic glosses, distributed around the external frame or in between lines. In such cases, it is clear that the annotations are not systematic in nature and can easily be positioned in any area close to the passage to be interpreted, without any great effort being made to coordinate the two pieces of text, since the space available on the page was larger than it needed to be.

The first phase of the research therefore consisted in conducting a census of the manuscripts containing the annotated Codex Justinianus with gloss. A subsequent step consisted in selecting the codices in which the gloss apparatus matched the characteristics mentioned above-in other words, those in which it was stable and continuous. With this objective in mind, Gero Dolezalek's ${ }^{40}$ catalogue was utiliseda resource that represents an invaluable tool, as it includes all the manuscripts of the works of Roman law that have come down to us starting from the earliest times up until 1600. Dolezalek, in describing the surviving witnesses, flagged up the presence or absence of glosses, apparatuses and additiones (i.e. the glosses of new jurists added to an ordinary apparatus), specifying the author or authors by name or by means of their initials. The information reported by Dolezalek derives only in part from an autoptic investigation, whilst in the majority of cases it is the fruit of perusals of library catalogues and of an ample bibliography relating to the subject.

This approach entailed a twofold selection of material useful for the investigation, since from the original, theoretical, sample, constructed on the basis of the information furnished by Dolezalek, it was necessary to eliminate a certain number of manuscripts whose characteristics did not correspond to the indications given in the catalogue, and therefore were devoid of some of the parameters necessary for the investigation.

The manuscripts of the Codex of Justinian listed by Dolezalek total 302. Based on a preliminary count, 190 turned out to be suitable for the investigation, whilst 86 had to be eliminated, since they lacked an apparatus or were equipped with only marginal glosses. Moreover, 26 appeared to be doubtful. Of the 68 manuscripts theoretically present in the libraries of the centres included in the investigationVatican City, Rome, Paris, Florence and Bologna ${ }^{41}$-it was necessary to eliminate 27, because they lacked an uninterrupted apparatus. Hence, a total of 41 manuscripts

40 Dolezalek 1972.

41 Manuscript 286 of the Biblioteca del Collegio di Spagna in Bologna was replaced with manuscript E.I.2 of Turin's Biblioteca Nazionale, since I was not granted permission to access the Bolognese library. 
was arrived at, equating to $25.15 \%$ of the suitable candidates, which at this point had dwindled to $163 .{ }^{42}$ In all cases, the gloss was that of Accursius. ${ }^{43}$

The selection of incunabula proved to be less problematical. In order to carry out a preliminary analysis of the phenomena under investigation, with the objective of comparing manuscript volumes with printed books, it was considered sufficient to work with a limited number of witnesses. Therefore, a total of five incunabula were examined. The sources used to locate these were vol. VII of the Gesamtkatalog and vol. VIII of the Indice generale degli incunaboli delle biblioteche dl'Italia. Given that no specific preconditions were required-other than that a continuous apparatus must be present, and that the volume should not be a reprint of an earlier edition ${ }^{44}$-volumes were selected based on their greater degree of availability..$^{45}$

42 This percentage is probably too low, given that one cannot be certain that the 122 codices, which are theoretically suitable, but which have not been scrutinised, are endowed with all the characteristics considered necessary for carrying out this kind of research.

43 The following codices were used: Città del Vaticano, Biblioteca Apostolica Vaticana, Barb. lat. 1462, Borg. lat. 224, Borg. lat. 372, Pal. lat. 757, Pal. lat. 758, Pal. lat. 759, Pal. lat. 760, Pal. lat. 762, Reg. lat. 1120, Ross. lat. 582, Urb. lat. 165, Vat. lat. 1428, Vat. lat. 1429, Vat. lat. 1430, Vat. lat. 11598; Florence, Biblioteca Medicea Laurenziana, Edili 68, Santa Croce Plut. 6 sin. 4, Santa Croce Plut. 6 sin. 5; Paris, Bibliothèque de l'Arsenal, 689; Bibliothèque nationale de France, Par. lat. 4521 A, Par. lat. 4521 B, Par. lat. 4521 C, Par. lat. 4522, Par. lat. 4523, Par. lat. 4524, Par. lat. 4526, Par. lat. 4527, Par. lat. 4530, Par. lat. 4531, Par. lat. 4532, Par. lat. 4535, Par. lat. 8940, Par. lat. 8941, Par. lat. 14342, Par. lat. 16912, Par. lat. 16913, Par. lat. 16914; Rome, Archivio di Stato, S.S. Salvatore 999; Biblioteca Casanatense 230; Biblioteca Vallicelliana, A 12; Turin, Biblioteca Nazionale, E.I.2. For further information, in addition to the already cited study by Dolezalek, see also Avril / Gousset 1984; Dolezalek 1985; Dolezalek 1972; Rota 1935; Soetermeer 1990, and Soetermeer 1997; Speciale 1994.

44 Here, the term 'reprint' means the identical re-publication, typographically speaking, of a work. The recomposition of a text in this way entails maintaining the original mise en page, which ensures that the original arrangement does not end up being lost from the model text.

45 The following incunabula were used: Venezia 4, VIII 1482, Andrea Torresano (Città del Vaticano, Biblioteca Apostolica Vaticana, Prop. II, 209); Norimberga, 30 I 1488, Anton Koberger (Roma, Biblioteca Casanatense, 912; Venezia 8, XII 1488, Battista de Tortis (Roma, Biblioteca Nazionale Centrale Vittorio Emanuele II, 70.3.G.2.V); Venezia, 3 X 1489, Andrea Torresano (Roma, Biblioteca Corsiniana 50.G.12); Venezia, 10 I 1493/94, Battista de Tortis (Città del Vaticano, Biblioteca Apostolica Vaticana, Prop. II, 213). In the last thirty years of the $15^{\text {th }}$ century, Venice represented the most important European location for the production of law books: indeed, in the period spanning 1481 to 1490 , the city generated $44 \%$ of juridical texts dating from before 1400 (especially Roman law), and in the following decade the percentage reaches 63\% (see Coq / Ornato 1988, 314-319). On the first legal incunabula produced in Venice, see Lowry 1991, 137-172 (the chapter titled The Lawyers and the Friars). As regards the Codex Justinianus in the 29 incunabula present in Volume VII of the Gesamtkatalog, 17 were printed in Venice. None of the incunabula relative to the cornerstone works in the Codex Iuris Civilis and listed in the Gesamtkatalog was produced in Bologna, which suggests that the city was still a rather small marketplace for the printed book, a hypothesis which is reinforced by Curt Bühler's view that there was robust activity in the 
The overall chronological distribution of the manuscripts sample and the chronological division within the two most represented centuries is summarised in pie Charts $1-3$. Table 1 contains information on the format, ${ }^{46} \operatorname{size}^{47}$ and proportions ${ }^{48}$ of all the volumes.

\begin{tabular}{|c|c|c|c|}
\hline \multicolumn{3}{|c|}{ Average size and proportion of codices and incunabula } & \multirow[t]{6}{*}{ tab. 1} \\
\hline & Codices & Incunabula & \\
\hline${ }_{1} \mathrm{H}(\mathrm{mm})$ & $1^{428.44}$ & $\left.\right|^{426.11}$ & \\
\hline ।W(mm) & |262.91 & |263.81 & \\
\hline , W + H (mm) & |691.35 & |689.22 & \\
\hline ,W/H & | 0.615 & |0.620 & \\
\hline
\end{tabular}

Tab. 1: Average size and proportion of codices and incunabula

$15^{\text {th }}$ century for the commercial production of manuscripts connected with the university. See Bühler 1958, 18-19, 27, and also Sorbelli 1929, 1-75, and Balsamo 1988).

46 In this case, the term 'format' is used to mean the 'dimensions du volume in hauteur et en largeur', Muzerelle 1985 (also in the revised and expanded Italian version, Maniaci 1996 [19982], 127). Concerning the different definitions of the term, see Lemaire 1989, 34-36.

47 Here, the term 'size' is used to mean the sum of the height and width $(\mathrm{H}+\mathrm{L}=\mathrm{H}+\mathrm{W})$ of a volume, which corresponds to the semi-perimeter, see Bozzolo / Ornato 1980, 217. On the subject of manuscript dimensions, in medieval catalogues reference is made to the forma parva (ranging from $235 \mathrm{~mm} \times 173 \mathrm{~mm}$ to 190 $\mathrm{mm}$ to $135 \mathrm{~mm}$ ), mediocris (ranging from $380 \mathrm{~mm} \times 250 \mathrm{~mm}$ to $245 \mathrm{~mm}$ to $165 \mathrm{~mm}$ ) and magna (ranging from $600 \mathrm{~mm} \times 390 \mathrm{~mm}$ to $435 \mathrm{~mm}$ to $305 \mathrm{~mm}$ ), Pizzo 1973, 47-48. These measurements roughly correspond to the divisions used by Carla Bozzolo and Ezio Ornato in their study of the dimensions of sheets in French medieval manuscripts, where manuscripts measuring under $320 \mathrm{~mm}$ are defined as petits, those ranging from $321 \mathrm{~mm}$ to $490 \mathrm{~mm}$ in size are termed petit-moyens, and those measuring more than $670 \mathrm{~mm}$ moyengrands; (Bozzolo / Ornato 1980). The relationship between the dimensions of a manuscript and the writing material has recently been addressed by Gumbert 1993, 227-263.

48 The proportion of a volume is expressed through the relationship between its width and height $(\mathrm{L} / \mathrm{H}$ $=\mathrm{W} / \mathrm{H})$. One speaks of an invariable proportion when the 'proportion d'un rectangle dont le rapport du petit côté est égal à $1 / \sqrt{2}$, et qui a pour propriète de donner deux moités conservant cette même proportion lorsqu'on divise en deux le grand côté', Muzerelle 1985, 101 (Maniaci 1996 [19982], 144). In practice, the proportion $1 / \sqrt{2}$ (i.e. 0.707 ) is the only one which has the characteristic of remaining the same when successive symmetrical folds of a sheet are made. Accordingly, one defines as 'étroite une proportion inférieure à la proportion invariante; large une proportion supérieure à la proportion invariante’, (Bozzolo / Ornato 1980, 219). 


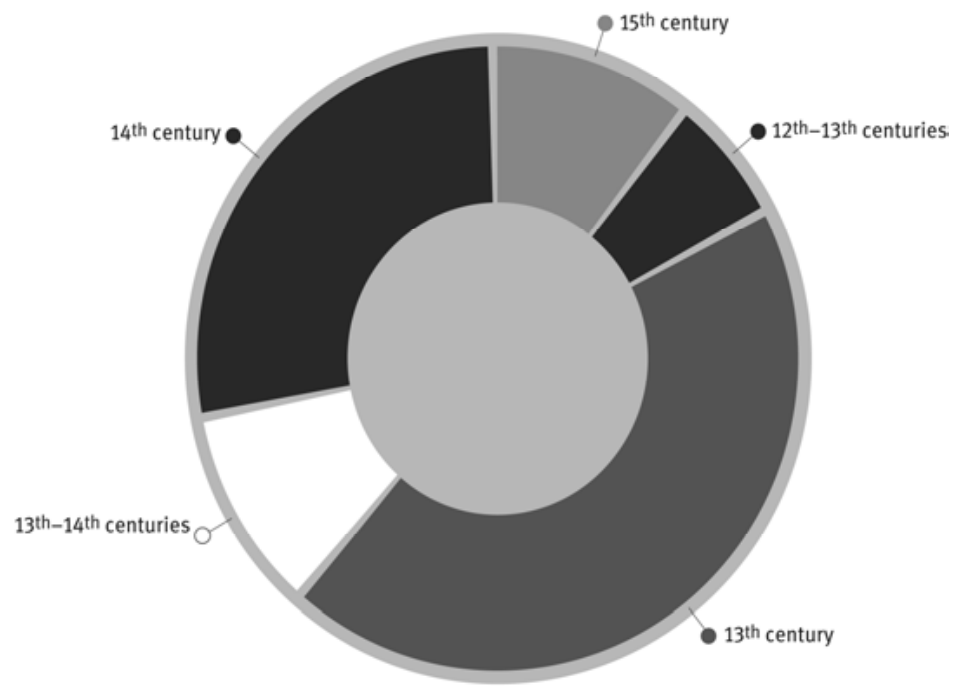

\section{Chart 1: Chronological distribution}

\section{Chronological distribution, $13^{\text {th }}$ century}

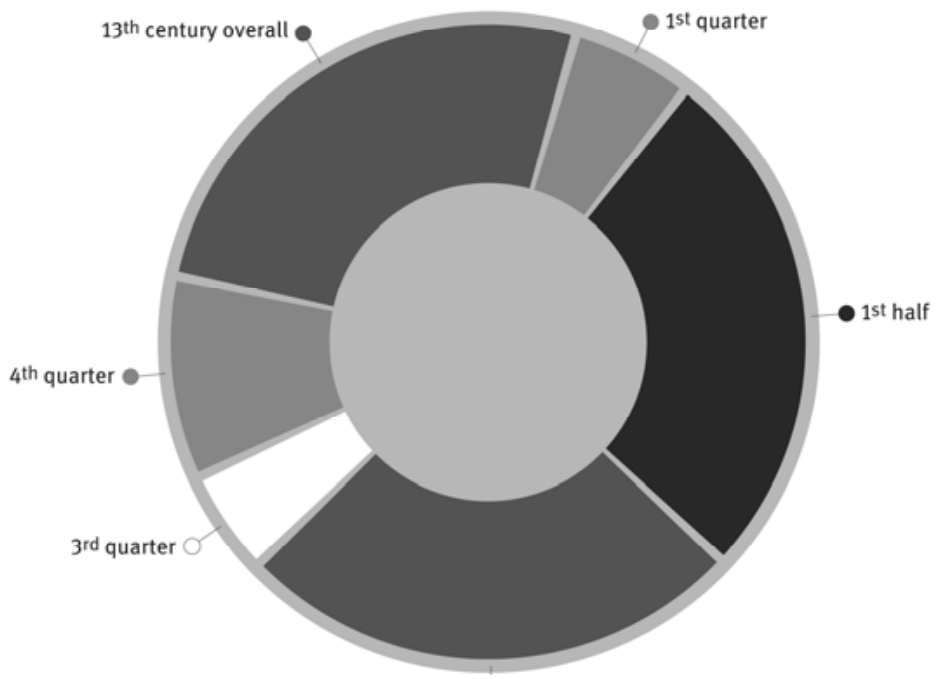

Chart 2: Chronological distribution, $13^{\text {th }}$ century 


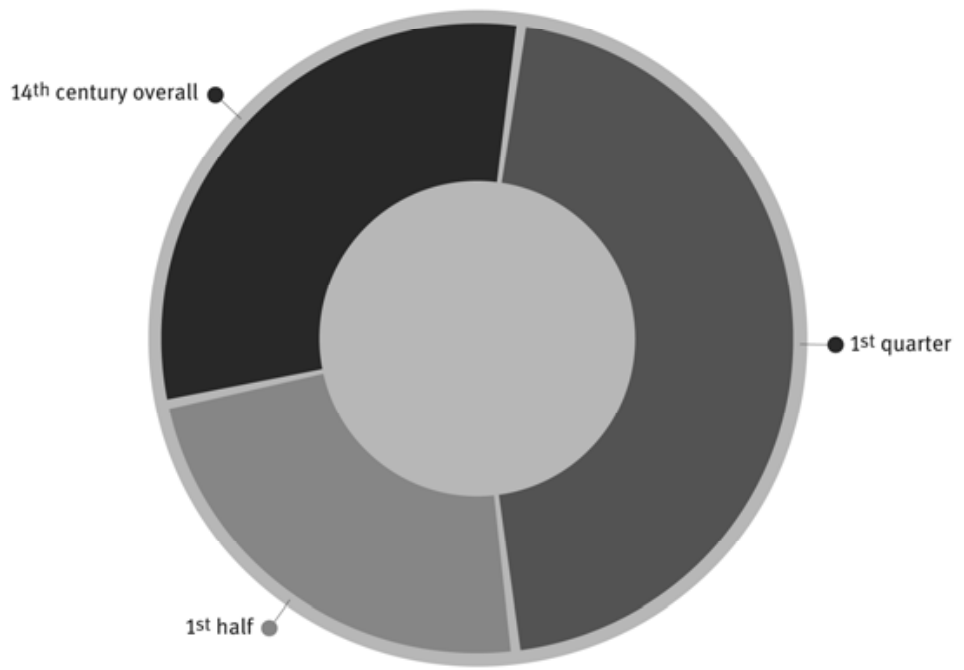

Chart 3: Chronological distribution in the $14^{\text {th }}$ century

\section{The mise en page}

The study of the mise en page, which is to say the 'disposition générale des différents éléments figurants sur une page', ${ }^{49}$ was carried out by identifying 17 sectors on the surface of the page which correspond to the areas occupied by the text, gloss and unfilled space. The said areas are represented by the two columns of text (Fig. 1); the six branches of the apparatus (Fig. 2); the four margins (upper, lower, inner and outer, Fig. 3); the intercolumnar space (Fig 4); and the four sides of the 'moat', which is to say the internal 'corridor' that separates the two columns of text from the branches containing the glosses (Fig. 5).

49 Muzerelle 1985, 109 (Maniaci 1996 [1998²], 159). 
Sectors corresponding to text, gloss and unfilled

space on the surface of the page

1

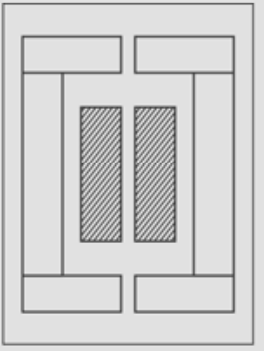

2

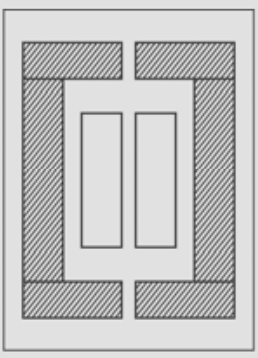

3

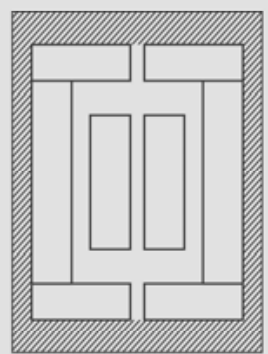

4

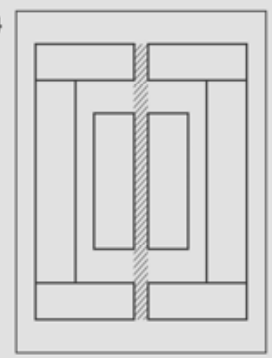

5

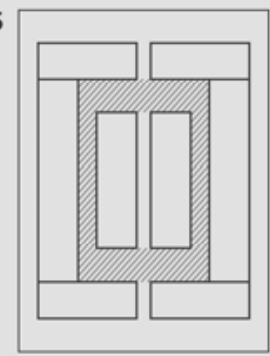

Fig. 1-5: Sectors corresponding to text, gloss and unfilled space on the surface of the page

The sizes of these spaces are arrived at by combining 16 linear, 9 horizontal and 7 vertical measurements, taken as shown in the schema on page 528.

The horizontal measurements were carried out by starting consistently at the outer margin and working from left to right on the verso of leaves, and from right to left on the recto. Conversely, the vertical measurements were obtained by working from the top towards the bottom, and therefore from the upper margin towards the lower margin of each leaf.

The nine horizontal measurements, indicated by a cardinal number, correspond to the following segments:

\section{Verso of leaves}

$1=$ The distance between the boundary of the outside margin and branch $\mathrm{B} /$ column $a$ of the gloss.

$2=$ The width of branch $\mathrm{B} /$ column $a$ of the gloss. 
$3=$ The distance between branch B/column $a$ of the gloss and column $a$ of the text. $4=$ The width of column $a$ of the text.

$5=$ The distance between column $a$ and column $b$ of the text.

$6=$ The width of column $b$ of the text.

$7=$ The distance between column $b$ of the text and branch B/column $b$ of the gloss.

$8=$ The width of branch $\mathrm{B} /$ column $b$ of the gloss.

$9=$ The distance between branch B/column $b$ of the gloss and the boundary of the inner margin.

\section{Recto of leaves}

$1=$ The distance between the boundary of the outside margin and branch $\mathrm{B} /$ column $b$ of the gloss.

$2=$ The width of branch $\mathrm{B} /$ column $b$ of the gloss.

$3=$ The distance between branch $\mathrm{B} /$ column $b$ of the gloss and column $b$ of the text.

$4=$ The width of column $b$ of the text.

$5=$ The distance between column $b$ and column $a$ of the text.

$6=$ The width of column $a$ of the text.

$7=$ The distance between column $a$ of the text and branch B/column $a$ of the gloss.

$8=$ The width of branch $\mathrm{B} /$ column $b$ of the gloss.

$9=$ The distance between branch B/column $a$ of the gloss and the boundary of the inner margin.

The measurement of the vertical axis of the page was carried out only once on either column $a$ or column $b$, which for branches A and C of the gloss exhibited a greater number of lines, and therefore a larger measurement. The seven vertical measurements, indicated by a Roman numeral, correspond to the following segments:

$\mathrm{I}=$ The distance between the boundary of the upper margin and branch A of the gloss.

II $=$ The height of branch A of the gloss.

III = The distance between branch A of the gloss and the column of text.

IV = The height of the column of text.

$\mathrm{V}=$ The distance between the column of text and branch $\mathrm{C}$ of the gloss.

$\mathrm{VI}=$ The height of branch $\mathrm{C}$ of the gloss.

VII = The distance between branch $\mathrm{C}$ of the gloss and the boundary of the lower margin. 


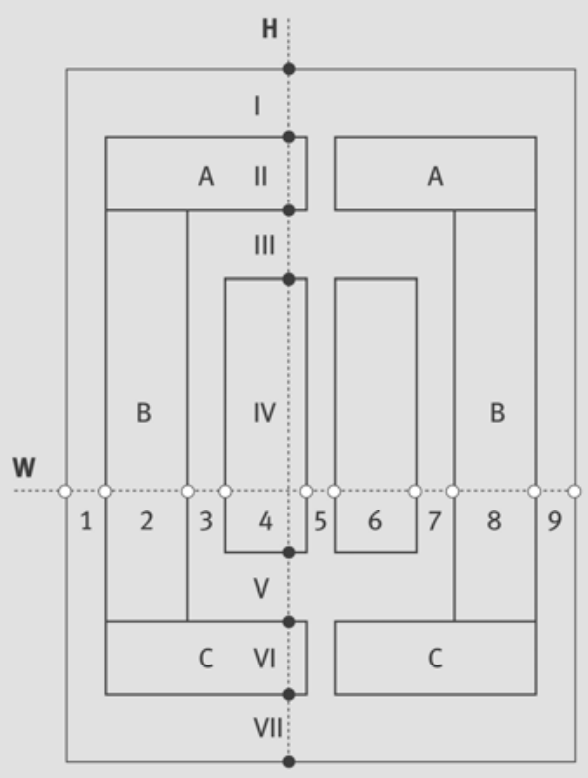

Fig. 1-5B: Division of the page into sectors

\section{The hierarchy of dimensions and their interconnection}

The investigation of the 'architecture' of the page based on the arrangement and structuring of the elements described above necessitated an important preliminary operation that consisted in the standardisation of data.

To 'standardise' means to render the values of the individual segments which make up a page-whether they be horizontal or vertical-independent from the (variable) dimensions of volumes. Books, in fact, follow a proportionality criterion based upon which all the constituent components of the written page are-largely 
speaking ${ }^{50}$ - positively correlated to the dimensions of the volume. Essentially, this governing principle caters to aesthetic needs, the goal being to balance exigencies with respect to the transmission of a message with the potential-and limits - of the material support destined to accommodate it.

To fulfil this goal, the average and standard deviation ${ }^{51}$ of each horizontal and vertical segment in each manuscript and incunabulum were calculated. Next, the average was subtracted from the value of each segment and the result divided by the standard deviation. In this way, the individual values can be centred with respect to the average and reduced with respect to the standard deviation.

In Charts 4 and 5, which present the standardised values of the horizontal and vertical volumes (i.e fields) of the page, the values turn out to be positive and negative in relation to the average, which corresponds to a value of 0 , and are therefore an expression of the greater or lesser reach of each individual segment with respect to the average.

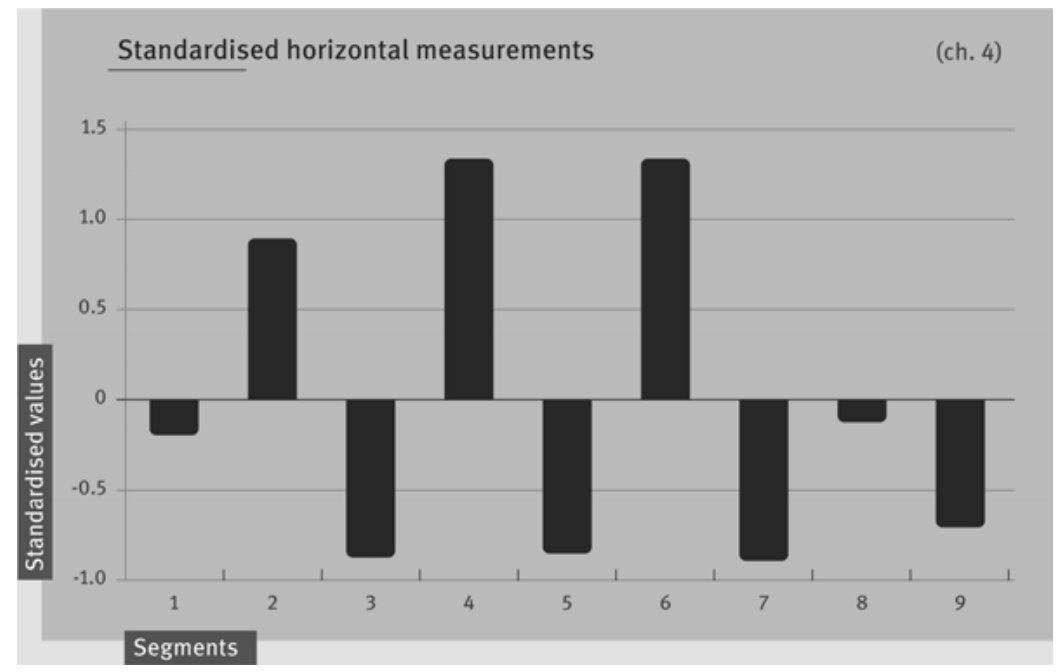

Chart 4: Standardised horizontal measurements

50 One cannot exclude some exceptions to this rule, since 'l'artisan pouvait prendre un certain nombre de libertés par rapport à ce principe, pourvu qu'elles demeurent noyées dans l'aspect d'ensemble de la page écrite' (Ornato 1994, 10, No. 11).

51 The standard deviation ( $\sigma$ ) represents, within a distribution, the square root of the arithmetic mean of the square distances between each value and the mean value; in other words, the square root of the variance; see also footnote 54 . 


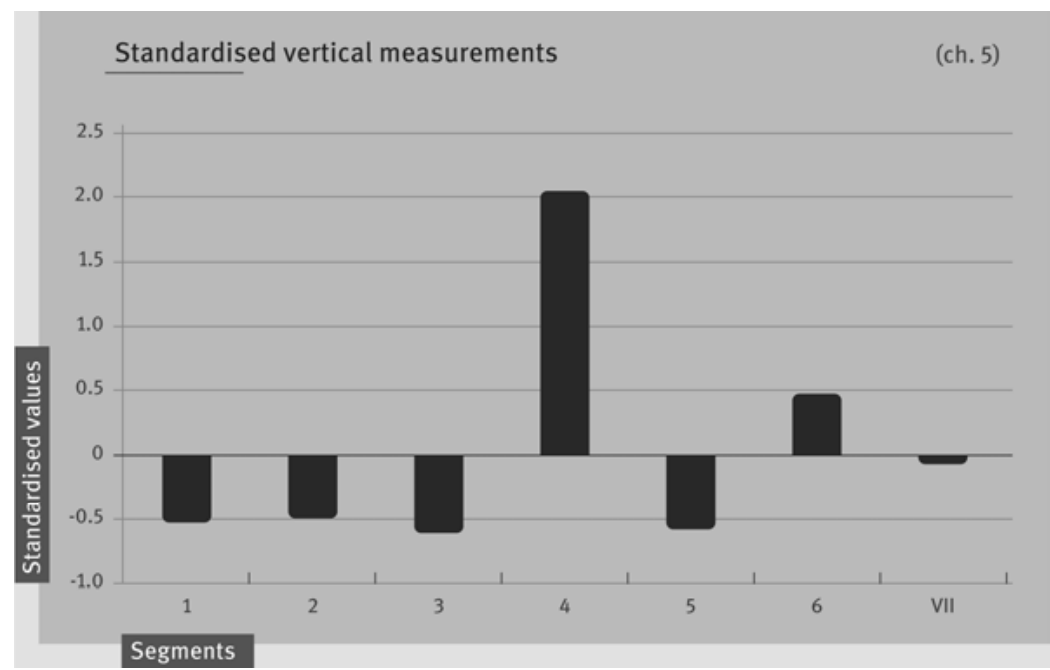

Chart 5: Standardised vertical measurements

As regards the horizontal area of the page, segments $3 / 5 / 7$, which correspond to the intercolumnar space and the 'moat' that separates the text zone from the gloss zone, appear to be very similar in size. Segments $4 / 6$, which correspond to the two columns of text are equal in size, and, proportionally, the largest. Segments $2 / 6$ are dissimilar; these correspond to the two lateral branches of the annotated area, that is to say zone B of the gloss-segment 2 tends to be decidedly larger than its mirrored counterpart, segment 8 . The values for segments $1 / 9$, which correspond to the margins, are negative, with the inner margin showing a lower value.

Now we come to the standardised vertical measurements: the upper margin and the first branch of the gloss, which is to say segments I/II, are equal, as is also the case with segments III/V, which correspond to the 'moat'. The most expansive area is, once again, that which corresponds to the column of text, segment IV, whereas the relatively large difference between segments VI/VII should be noted, along with the even greater disparity between segments II/VI, which correspond to the upper and lower branches of the gloss.

These preliminary data already reveal, with considerable clarity, a characteristic uniformity, both vertically and horizontally, with respect to the central area of the page, framed by the branches of the apparatus and incorporating the 'moat', the two columns of text and the intercolumnar space. 
The two lateral margin areas prove to be rather less uniform, and therefore further comparison of the standardised averages of the individual segments is called for. If one adds up the values of segments $1 / 2 / 3$ and those of segments $7 / 8 / 9$, an average value of -0.16 to -1.68 is obtained. Given that, as we have already seen, segments $3 / 7$ are broadly speaking equal (the difference between the two is just 0.019), the discordance in their reach is caused in the first place by the two lateral branches of the gloss, and secondly by the corresponding margin. Indeed, segment 2 always proves to be larger than segment 8 (difference segm. 2 - segm. $8=1$ ), and likewise, but to a lesser degree, segment 1 turns out to be larger than segment 9 (difference segm. 1 - segm. $9=0.49$ ).

The two lateral vertical margin areas exhibit similar discordances. If one adds up the standardised values of segments I/II/III and those of segments V/VI/VII, an average value of -1.71 to -0.31 is obtained, and since segments III/V are almost equal (difference segm. III - segm. $\mathrm{V}=0.017$ ), the differences between the volumes have to be sought in segments I/II and VI/VII. Segment VI always turns out to be larger than segment II (difference segm. VI - segm. II = 0.94), and similarly, segment VII is larger than segment I (difference segm. VII segm. $I=0.44$ ).

At this point in the investigation it is interesting to note the type of correlation $^{52}$ that exists between the horizontal and vertical segments of the page (see Tab. 2 and 3).

If one examines Table 2, which presents the standardised horizontal measurements of the page, a clear correlation between segments $4 / 6$, the two text columns, segments $3 / 5 / 7$, the lateral branches of the 'moat' and the intercolumnar space, segments $2 / 8$, the lateral branches of the gloss, segments $1 / 9$, and the inner and outer margins of the page becomes quite obvious.

Conversely, a negative correlation can be identified between segments 2/8 and $4 / 6$, the two lateral branches of the gloss and the text columns, which demonstrates that as the size of the text increases, the corresponding lateral gloss decreases in size, leaving the dimensions of the 'moat' unchanged.

52 A statistical correlation function makes it possible to express the link between two variables, which is to say whether when one increases the other decreases, or vice versa, or if they increase or decrease in tandem. If the result is 0 , there is no correlation, whereas a value that approaches +1 or -1 indicates the presence of a positive or negative correlation. 
Correlation between the horizontal segments of the page

(tab. 2)

\begin{tabular}{|c|c|c|c|c|c|c|c|c|c|}
\hline & 1 & 2 & 3 & 4 & 5 & 6 & 7 & 8 & 9 \\
\hline$\left.\right|^{1}$ & 1.000 & & & & & & & & \\
\hline $1^{2}$ & $I^{-0.588}$ & | 1.000 & & & & & & & \\
\hline $1^{3}$ & $1^{-0.541}$ & $\left.\right|^{-0.041}$ & 1.000 & & & & & & \\
\hline $1^{4}$ & 0.229 & $1^{-0.846}$ & 0.224 & |1.000 & & & & & \\
\hline $1^{5}$ & $\left.\right|^{-0.604}$ & 0.046 & | 0.871 & $\left.\right|^{0.141}$ & 1.000 & & & & \\
\hline 16 & 0.242 & $\left.\right|^{-0.858}$ & 0.249 & 0.974 & 0.154 & 1.000 & & & \\
\hline $1^{7}$ & $\left.\right|^{-0.483}$ & $\left.\right|^{-0.120}$ & 0.971 & $\left.\right|^{0.277}$ & 0.853 & 0.297 & 1.000 & & \\
\hline $1^{8}$ & $1^{-0.359}$ & $\left.\right|^{0.652}$ & $\left.\right|^{-0.395}$ & $1^{-0.642}$ & $1^{-0.305}$ & $\left.\right|^{-0.701}$ & $1^{-0.453}$ & | 1.000 & \\
\hline 9 & |-0.620 & $\mathrm{I}^{-0.687}$ & $\mathrm{I}^{-0.261}$ & | 0.382 & $\left.\right|^{-0.281}$ & 0.446 & $\left.\right|^{-0.171}$ & $\left.\right|^{-0.690}$ & | 1.000 \\
\hline
\end{tabular}

Correlation between the vertical segments of the page

(tab. 3)

\begin{tabular}{|c|c|c|c|c|c|c|}
\hline $\mathbf{I}$ & II & III & IV & V & VI & VII \\
\hline | 1.000 & & & & & & \\
\hline $1^{-0.005}$ & |1.000 & & & & & \\
\hline $1^{-0.058}$ & |0.358 & 1.000 & & & & \\
\hline |0.326 & | 0.573 & |0.578 & |1.000 & & & \\
\hline$\left.\right|^{-0.120}$ & | 0.325 & 0.905 & | 0.578 & | 1.000 & & \\
\hline$\left.\right|^{-0.377}$ & $1^{-0.433}$ & $\left.\right|^{-0.271}$ & $\left.\right|^{-0.880}$ & $1^{-0.277}$ & |1.000 & \\
\hline |0.094 & $1^{-0.265}$ & $\left.\right|^{-0.539}$ & | 0.072 & $\left.\right|^{-0.501}$ & $1^{-0.500}$ & 1.000 \\
\hline
\end{tabular}

Tab. 2-3: Correlation between the horizontal / vertical segments of the page

Concerning the vertical volumes, the degree of correlation between the individual segments appears to be less systematic (Tab. 3). There is a positive relationship between segments III/V and the upper and lower branches of the 'moat', which provides further evidence of the geometric uniformity reserved for this area of the page. The relationship between these two branches of the 'moat', the two text columns, and segments III/IV/V is on average positive, whereas there is a negative correlation between the last three vertical columns of the page, which correspond to segments $\mathrm{V} / \mathrm{VI} / \mathrm{VII}$, in contrast to the upper area, represented by segments I/II/III, between which there is no correlation. 
Based on these preliminary observations, some fundamental trends can be observed vis-à-vis the 'construction' of the page.

Within a space that is generally oblong in form, the width measurements, which are lower than the height measurements, tend to 'discipline' the volumes in a lateral direction. Conversely, the volumes have more opportunity to grow in a vertical direction.

The most uniform zone, namely that where the size of the volumes and the relationships between them is clearly more stable, extends from segment 3 to segment 7, and from segment III to segment V, and therefore includes the 'moat', the intercolumnar space and the two text columns. Additionally, the same area proves to be somewhat shifted towards the inner margin, and rather more obviously shifted towards the upper margin of the page.

In the outer zone of the page, in a horizontal direction, we find the two lateral branches of the gloss and the inner and outer margins, which despite being decidedly more variable and generally non-uniform (segments $1+2+3>$ segments $7+8+9$ ), always maintain a close relationship both between themselves and with the inner horizontal volumes. The horizontal exploitation of the page therefore exhibits an established and systematic trend, and the 'architecture' of the internal volumes of the same space follows a 'rhythm' which gradually becomes more regular and constant as one progresses towards the inner portion of the page.

Conversely, the construction of the page in the vertical direction reflects a different strategy. The stable central nucleus is bounded by two areas (upper and lower) which the rectangular form renders more easy to exploit in terms of space, and which as a consequence are articulated in a looser and less systematic way. This pattern can be observed particularly in the lower portion of the page, because for technical and aesthetic reasons intrinsic to the manufacture of the medieval codex, the upper margin does not extend beyond a certain limit and is in any event generally narrower than the lower margin. ${ }^{53}$

As we have seen, no correlation exists between segments I/II, nor between them and the corresponding lower volumes, segments VI/VII, whereas there is a correlation, albeit negative, between segments V/VII. In addition, the sum of segments I/II is always lower than that of segments V/II. There is no significant degree of correlation between these vertical marginal and outer segments and the inner volumes, with the exception of the negative relationship that exists between seg-

53 The possible geometric procedures used in constructing the mise en page in the context of the medieval manuscript and printed book have been addressed by various authors, among whom should be mentioned: Bühler 1946; Tschichold 1965; Tristano 1991; Montecchi 1994; Maniaci 1995. 
ments III/V and segment VII (and this is due to the fact that whilst the 'moat' is largely speaking stable, the lower margin, as we shall see more clearly later on, exhibits a high degree of variability), and the consistently negative relationship between segments IV/VI.

The geometric strategy adopted for the page in a vertical direction is therefore much more elaborate in comparison to the horizontal one: indeed, the relationship between the individual volumes is a lot less systematic owing to a rather low interdependence. Significant exceptions are seen in the positive correlation between the central segments, II/IV/V, and the inversely proportional mechanism which governs the relationship between the size of the final branch of the gloss and that of the lower margin, segments VI/VII, and the relationship between the same segments with the text column, segment IV: it is here, in fact, that the interplay between the various volumes becomes most apparent.

\subsection{Variability}

Even if it has been possible to express the observed phenomenon through the average standardised measurements, based on the premise that within the internal area of the page the different volumes register values that are almost constant in the various cases considered, it was also necessary to further process the data in order to obtain indicators that represent the different quantitative modalities taken on by all the segments, and hence their variability, both within one and the same manuscript or incunabulum and across the overall corpus of manuscripts and incunabula.

In the first case, an index of relative variability was applied (known as the coefficient of variation), ${ }^{54}$ by means of which the variability of the vertical and horizontal segments within each unit can be expressed, and therefore the strat-

54 The coefficient of variation (CV) is expressed by the formula $\sigma /$ average $^{\star} 100$, where $\sigma$ represents the standard deviation, which is an index of absolute variability; in other words, it is an index expressed in the same unit of measurement as the terms of a distribution. Given that $\sigma$ is frequently correlated to the average (in fact, it is normal that within one and the same reference point-such as the page of a manuscript-the largest spaces are affected by more noticable variations), in order to express the variability of each segment of a page within each manuscript and incunabulum and to eliminate the dimensional effect, an index of relative variability is applied, namely CV. The use of variable relativity indices becomes necessary when distribution patterns are expressed in different units of measurement, or when such patterns are expressed in the same unit of measurement, but the average intensities (that is to say the range of the values examined) are different (as in our case), or when the distributions compared are composed of relationships. 
egy adopted in each instance-one could even say leaf-by-leaf-for each volume in one and the same manuscript or incunabulum. Accordingly, from hereon in we shall be referring to intra codicem variability.

On the other hand, in the second case, in order to express the variability of each segment within all the manuscripts and incunabula, the standard deviation (which represents an absolute index of variability) $)^{55}$ of the standardised average measurements was calculated (s). This makes it possible to observe the phenomenon in a transverse direction, so as to focus attention on how the choices made by the different artisans varied. Accordingly, from hereon in we shall be referring to inter codices variability.

If one studies Chart 6 , which relates to the total horizontal intra codicem variability measurements, one can see that the inconstancy turns out to be at its maximum along the outer margins, and then gradually decreases, although not with equal intensity, between the inner and outer zones, as one progresses towards the centre.

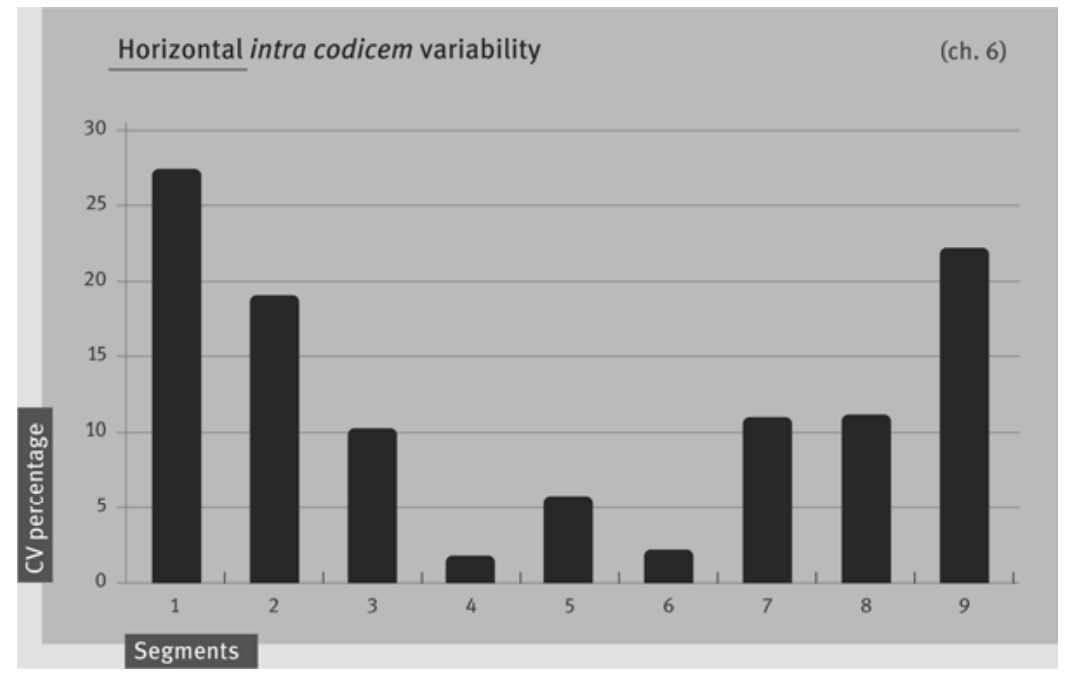

Chart 6: Horizontal intra codicem variability

55 In the standardised data, the average is 0 . In such cases, there is no correlation between the variation and the average. Furthermore, division by 0 , which is necessary to obtain the $\mathrm{CV}$, is impossible. 
Concerning the two lateral branches of the gloss-segments 2/8-once again it is the outer one which is most variable, whilst the central nucleus, composed of segments $3 / 4 / 5 / 6 / 7$, remains essentially uniform and exhibits a decidedly low variability index, especially with respect to the two text columns.

As regards the vertical intra codicem variability total (Chart 7), this shows values that are clearly much higher than those seen in the horizontal segments, as can readily be gleaned from the much higher levels marked on the scale. Plain to see is the irregularity of the lower margin, segment VII, in comparison to the upper part of the page, composed of segments I/II/III. Likewise, the text column proves to be rather variable.

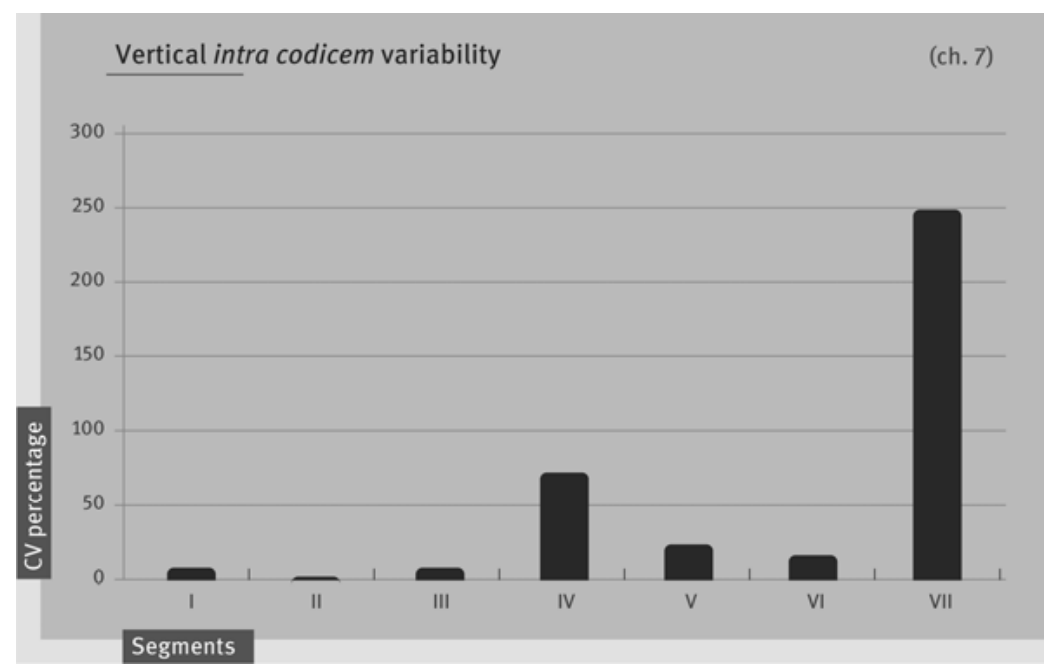

Chart 7: Vertical intra codicem variability

Within the overall corpus, for the horizontal zones (see Chart 8, which relates to total inter codices variability) a strategy aimed at better structuring the area that frames the central nucleus, composed of segments $1 / 2 / 8 / 9$, manifests itself. This is especially apparent in segments $1 / 2$, and slightly less so in the text column, represented by segment 4 . 


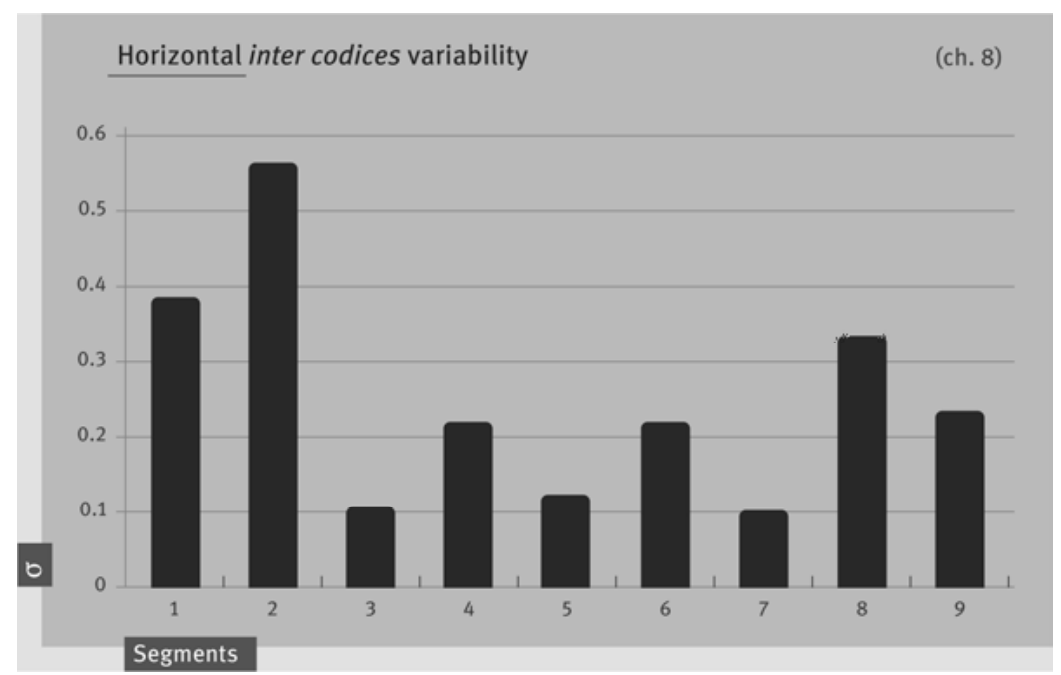

Chart 8: Horizontal inter codices variability

As for the vertical inter codices variability total (see Chart 9), the final branch of the gloss and the lower margin represent the volumes (segments IV/VII) that differ the most, the disparity being the result of a steady and continuous adjustment of one volume in relation to the other.

If one distinguishes between the manuscripts and the incunabula, the different strategies employed in the construction of the page become even more significant.

Chart 10, which relates to the horizontal intra codicem variability total, shows that the levels of variability in the incunabula are clearly lower than those of the manuscripts.

In any event, alongside a very uniformly structured central nucleus in the incunabula, and only slightly less so in the manuscripts, the two outer and marginal areas differentiate themselves in both book typologies owing to their far more articulated structures, even if they present some differences. The two lateral glosses of the incunabulum, segments $2 / 8$, which are almost identical, remain unchanged in comparison to the two blank 'corridors' they frame, segments $1 / 3$ and $7 / 9$, which present more obvious variations. Conversely, in the manuscript, one can once again make out the variability in the lateral zone, particularly in the outer area. 


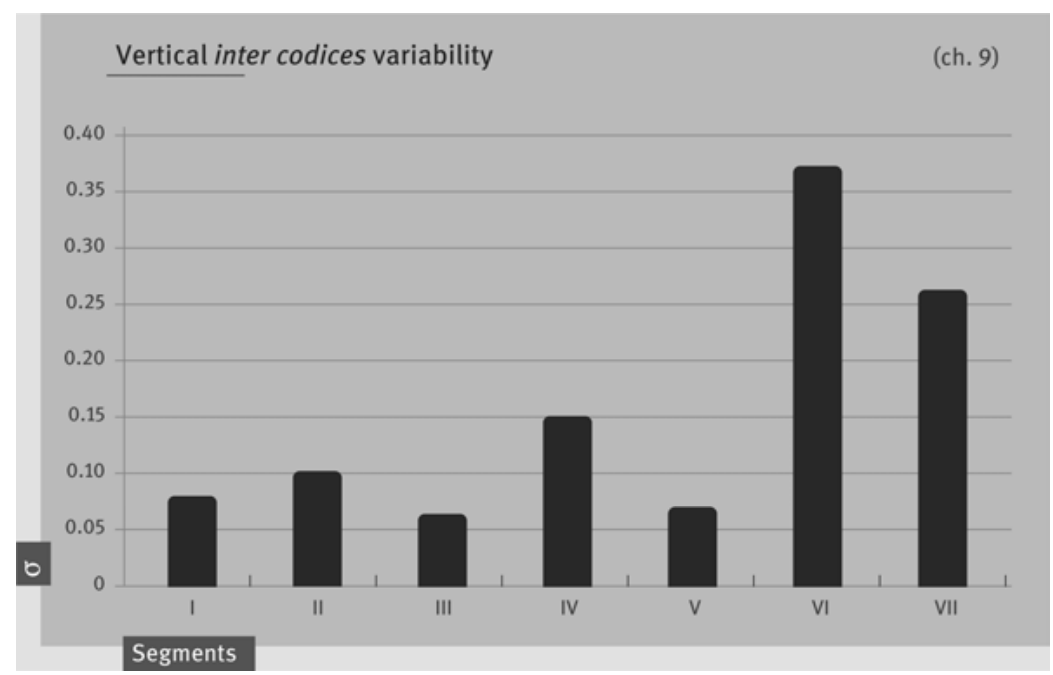

Chart 9: Vertical inter codices variability

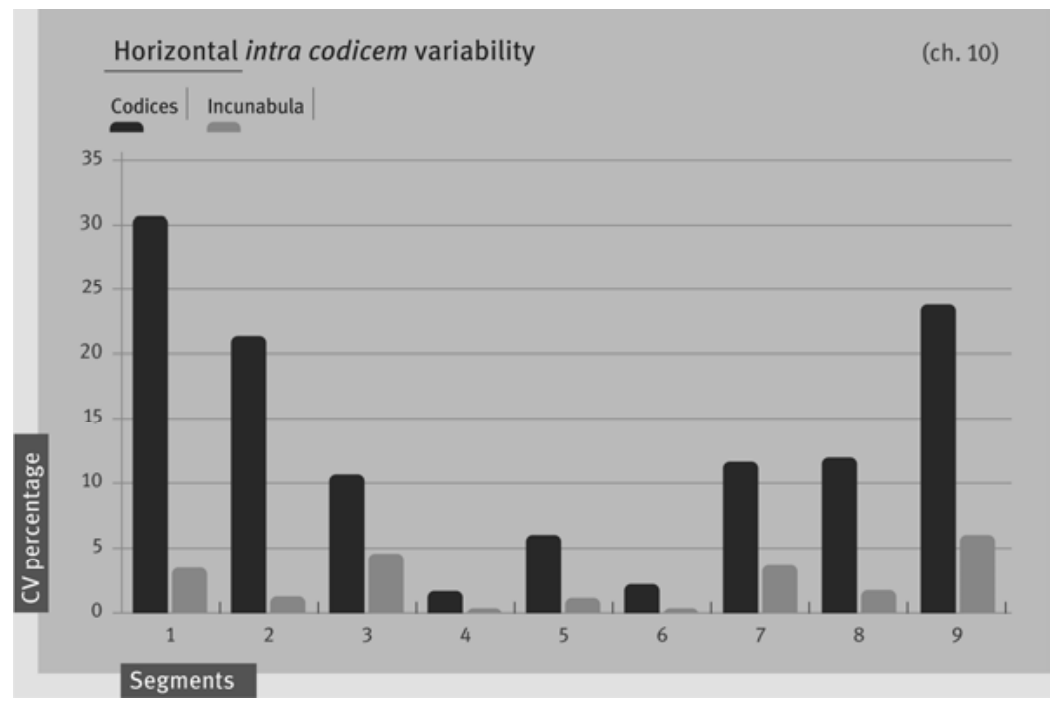

Chart 10: Horizontal intra codicem variability 
As for the vertical volumes (see Chart 11, which relates to vertical intra codicem variability), in the incunabulum, the text column, segment IV, exhibits the maximum degree of variability, whereas in the manuscript the greatest degree of irregularity is seen in the lower margin.

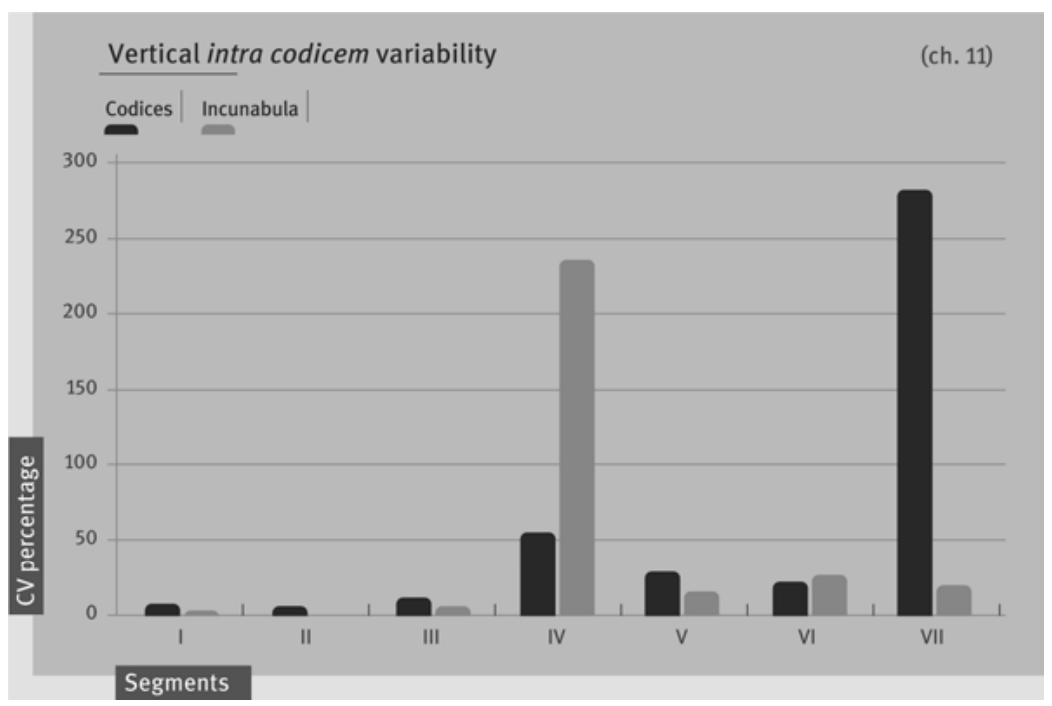

Chart 11: Vertical intra codicem variability

Moving on to the horizontal and vertical inter codices variability (Charts 12 and 13), in the first case, next to a uniform central nucleus, albeit one which is slightly more variable in the incunabula, we once again observe an outer marginal zone which is decidedly more articulated in appearance. In the case of the vertical measurements, maximum irregularity is seen in the lower volumes, represented by segments VI/VII.

A page construction strategy aimed at assuring maximum rigor in the central nucleus and more flexibility in the outer and marginal areas was adopted for the manuscript. Corresponding to an inner stability, one observes an outer irregularity which manifests itself in different ways and to varying degrees. Segments $1 / 2 / \mathrm{VI} / \mathrm{VII}$, which correspond to the outer and lower margins and the outer and lower branch of the apparatus, represent the volumes that were subject to the most adjustments-spaces which could be reshaped with greater liberty, and therefore linked, as we have seen, to an inversely proportional relationship. A lower degree of flexibility was reserved for the treatment of the mirroring volumes, segments $\mathrm{I} / \mathrm{II} / 8 / 9$, which are generally of smaller size and tend to vary less. 


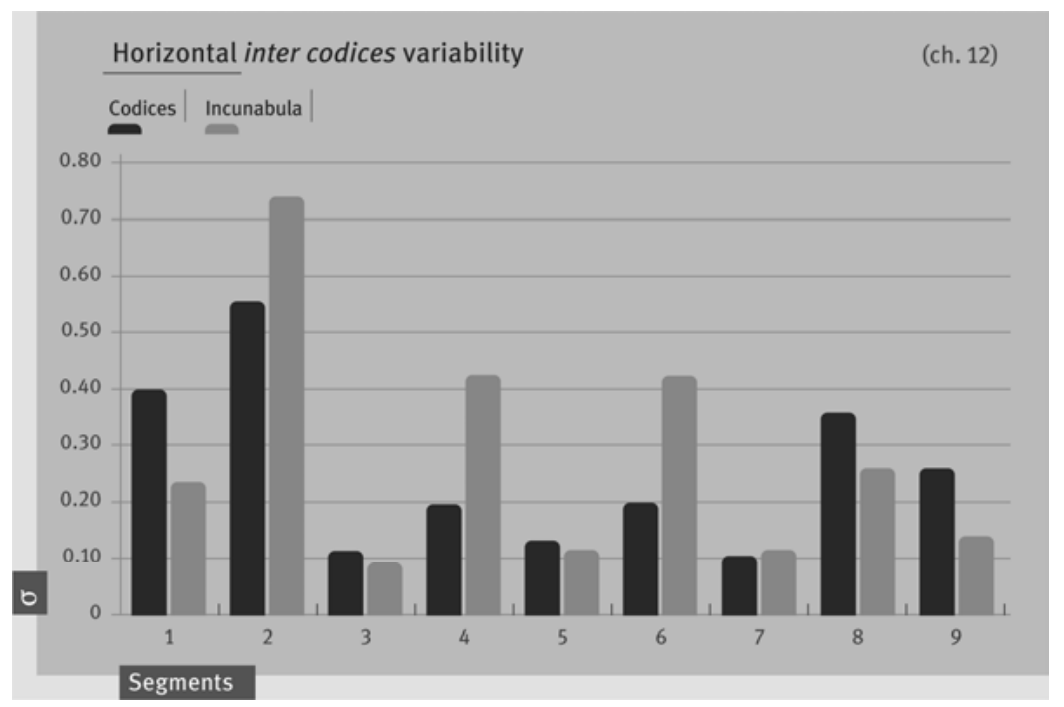

Chart 12: Horizontal inter codices variability

In the incunabulum, the phenomenon, despite registering values that are clearly lower than those seen in the manuscript, manifests itself in different ways. The dimensional relationships between the volumes of the page are comparable to those seen in the manuscript: the lower and outer margins are larger than the inner and upper ones, and the outer and upper branches of the gloss larger than the lower and outer ones. On the other hand, a more variable central nucleus corresponds to a regular outer frame, which is probably due to the printing technique employed. In fact, within one and same incunabulum the marginal zone did not vary, ${ }^{56}$ and therefore it was the internal zone that from time to time underwent the adjustments necessary for the continual adaptation of the two text masses to one another.

56 This is probably due to the fact that any modification of the marginal zone would have called for a change in the size of the shape, which would have involved additional work. 


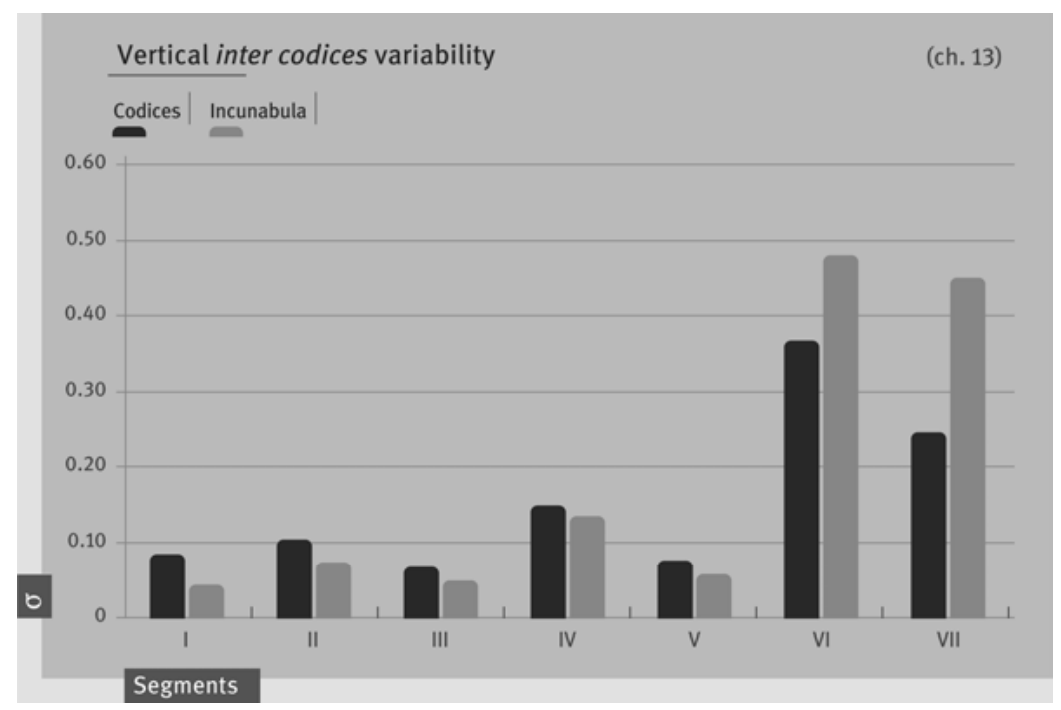

Chart 13: Vertical inter codices variability

One of the more significant characteristics of the shifts that occur in the volumes within the incunabulum is, without doubt, the extreme vertical irregularity of the text column, segment IV. This characteristic represents a manifestation of the progressive configuration on the page of the normative text in relation to the apparatus. In other words, the text could be lengthened or shortened as it was continually adjusted to the gloss, whose lower volumes also waxed and waned, somewhat like the pieces of an interlocking puzzle. In the incunabula, the organisation of the two text masses on the page depended, needless to say, on printing techniques, since these made it necessary to plan the arrangement of the text and gloss on the page throughout the entire volume. However, the presence of a vertical text column that was systematically variable in relation to the gloss is also met with in Bolognese manuscripts. ${ }^{57}$ If one scrutinises Charts 14 and 15, which illustrate the vertical intra codicem variability of Bolognese manuscripts and all those of different provenance, it becomes clear that in the former the variability tends to shift towards the centre of the page and reaches its maximum in segment IV, the

57 The manuscripts are: Borg. lat. 372, E.I.2, Pal. lat. 759, Par. lat. 4521 A, Par. lat. 4523, Par. lat. 4527, Par. lat. 4530, Par. lat. 4531, Par. lat. 4532, Par. lat. 4535, Par. lat. 8941, Par. lat. 16913, Laur. S. Croce plut. 6 sin 4, Urb. lat. 165, Vat. lat. 1430. This group of manuscripts constitutes the only sufficiently compact and significant geographical partition which can be identified in the sample and whose behaviour has been studied in various fields of research. 
text column, whereas in the latter the greatest degree of irregularity is concentrated in the lower margin, segment VII.

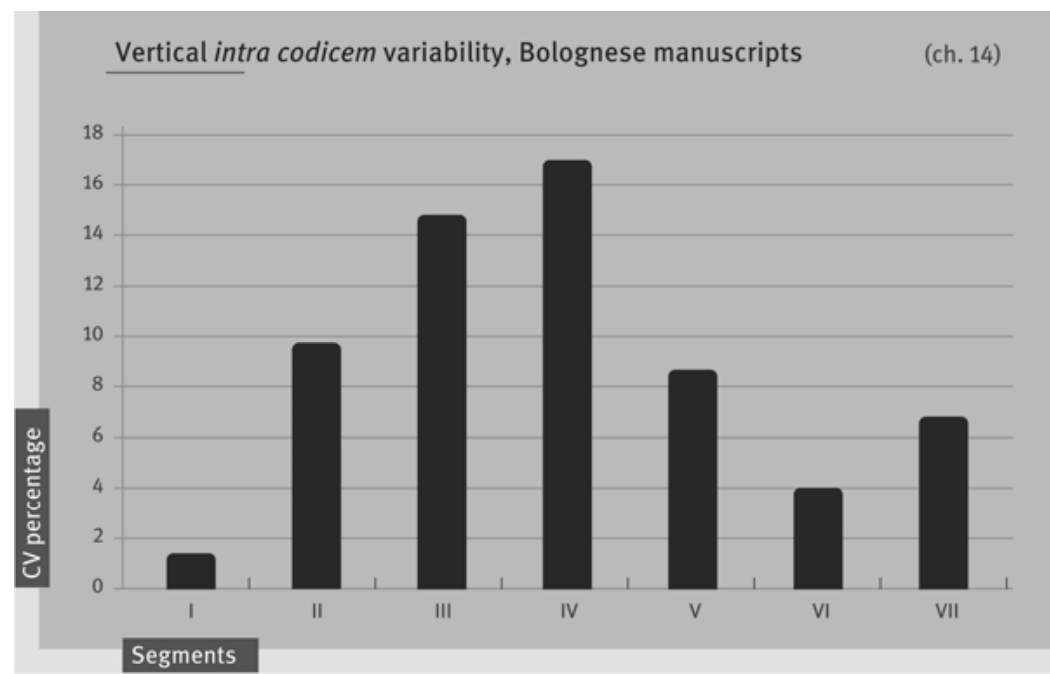

Chart 14: Vertical intra codicem variability, Bolognese manuscripts

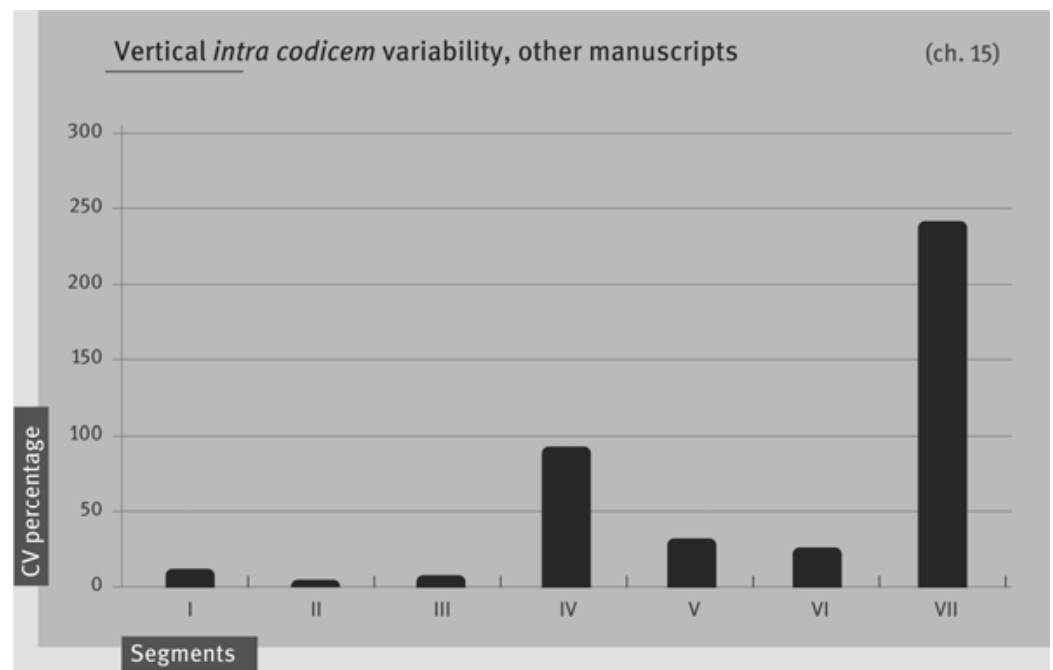

Chart 15: Vertical intra codicem variability, other manuscripts 
This means that whilst in the non-Bolognese manuscripts a strategy aimed at maintaining the stability of the text column and rendering the lower portion of the sheet more adaptable prevails, in the codices originating from Bologna all the volumes on the page participate in a mechanism which is clearly more complex. If, in a manuscript, the text column varies in a consistent way in parallel with the gloss, this points towards assiduous planning and a purposeful scheme which had to be implemented page after page in order to synchronise the two text masses with each other. In such instances, an essential prerequisite is that the writing of the text and of the gloss take place in parallel, even if such an expedient does not necessarily involve a planned diversified arrangement of the volumes on the page. In the Bolognese manuscripts, the adjustment of the volumes therefore tends to be carried out in accordance with specific procedures, which were the product of a particularly attentive page construction technique.

The technical reasons lying at the root of a page configuration aimed at maintaining a stable outer framework, in contrast to a more variable central nucleus, have already been addressed. However, could it be that aesthetic issues also played a role in the choices made? It is difficult to express an opinion on this matter, given that to the eyes of a present-day scholar a juridical incunabulum can be likened to a book equipped with a rich apparatus of footnotes whose sizes vary from page to page, with the text expanding or shrinking according to need, which in any event is contained within an unchanging framework. This illustration seems pertinent when one considers that in the printed editions of the Codex the text columns and the lower branches of the gloss are linked by an inversely proportional relationship and turn out to be the most variable sectors, whereas in the manuscripts the same kind of relationship is established between the final branch of the gloss and the lower margin and, albeit to lesser extent, between the outer margin and the central column of the apparatus, thereby violating an aesthetic principle, namely that of uniformity and the proportionality of margins-a principle which is not solely applicable to the printed book..$^{58}$ The different shifts in size

58 Ezio Ornato has formulated various hypotheses regarding the endurance over the centuries of the principle that governs the hierarchy and proportionality of margins. If in fact it is not to be ruled out that material restraints could have exerted an influence on this aspect of the book's structure, one should also not discount the effect of aesthetic considerations and those of taste, given that 'tous les phénomènes qui relèvent du goût-notamment dans le domaine des proportions-comportent une large part d'arbitraire au depart, et d'habitude par la suite: ce que nous sommes habitués à voir, devient normal, et ce qui est normal peut 
seen in the lower portions of the manuscript and incunabulum along the vertical axis of the page actually find some common ground in the group of codices originating from Bologna, in which the variability tends to move towards the centre of the page and reaches its apex precisely at the level of the text columns. This, as has already been said, could be indicative of continuous planning and adaptation of the two text masses carried out on a page-by-page basis, in accordance with a principle reminiscent of that used in typographical composition.

One could therefore say that where there is more planning vis-à-vis the relationships between the written areas and the non-written areas on the pagethanks to a more painstaking manual construction technique, as in the case of the Bolognese manuscripts, and a mechanical method, as in the case of the incunabula-the tendency is for greater articulation of the text with gloss (the graphical element), thereby respecting as much as possible the principle that governs the hierarchy of the margins.

To conclude, then, variability, even if it involves the entire page, manifests itself in a relatively contained way along the horizontal axis of the page, and in a clearer and more articulated manner in the vertical direction. Coinciding with greater stability, there is a higher degree of correlation in the horizontal volumes. This contrasts with the vertical volumes, for which, as we have seen, a high degree of freedom was exercised with respect to choices made and solutions employed.

In Chart $16,,^{59}$ the overall distribution of the variability measurements along the vertical and horizontal axes of the page within the entire sample is presented. It becomes immediately clear that in the majority of volumes the lowest level of variability is concentrated in the horizontal zones of the page, whilst the highest percentage occurs within the vertical ones.

se transformer rapidement en règle qu'il est nécessaire de suivre sous peine de choquer' (Ornato 1994, 16).

59 The graph takes a different form with respect to the previous ones, in that the number of volumes is shown on the $y$ axis, whilst the CV values are arranged along the $x$ axis. 


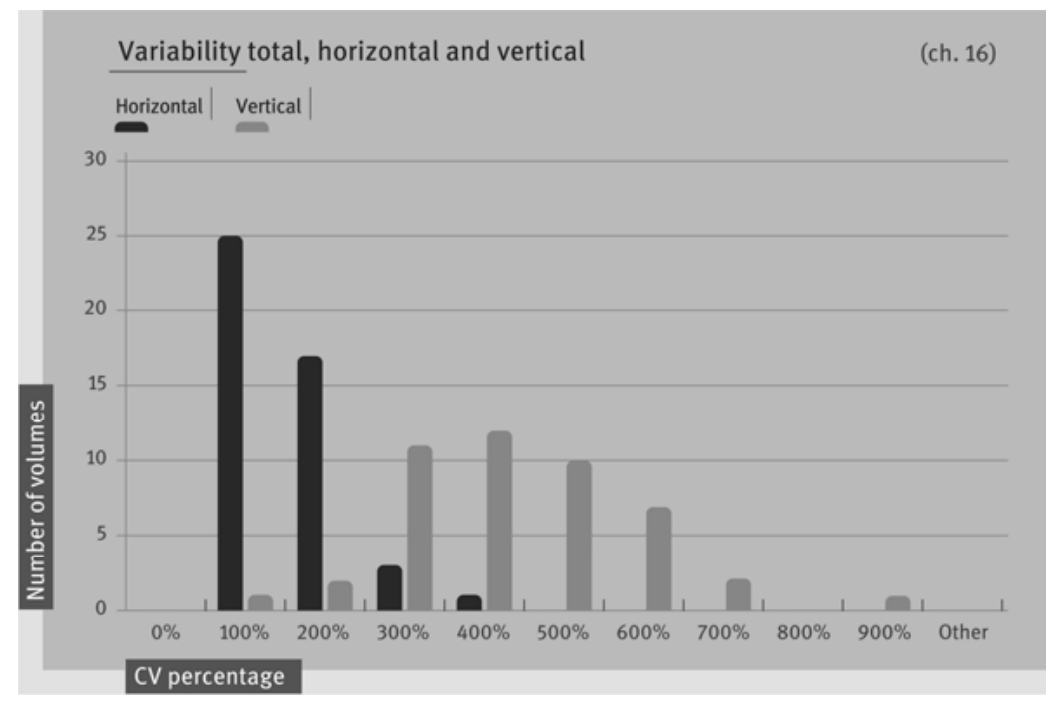

Chart 16: Variability total, horizontal and vertical

\section{Facing and overlying pages}

Having examined the relationships that exist between the individual volumes that constitute the page layout-in terms of dimensional hierarchy, correlation and variability-at this point in the investigation we should broaden our horizon and extend the analysis from single pages to neighbouring ones.

The objective, then, is to discover whether, and to what extent, the treatment of facing (verso-recto) and overlying (recto-verso) pages in a manuscript or incunabulum was the same as that adopted for individual pages, whether an aesthetic-formal choice that favours geometric and visual uniformity prevails, and finally if it is possible that such a strategy could have conflicted with the text/gloss adjustment mechanism, and hence with legibility requirements.

Therefore, the question being posed is whether or not the variability of the text/gloss composition is independent from the arrangement of pages (facingoverlying), and whether the aesthetic aspect (i.e. the uniformity of the composition) takes precedence over practical considerations (i.e. text/gloss adaptation).

When opened, a juridical codex generally presents an impression of great uniformity, with the recto/verso leaves appearing as mirrored 'reflections' of each other throughout the entire book. 
As we have seen, in reality such apparent regularity is to an extent only superficial, since some areas of the page are particularly variable in the way they present, and therefore tendentially not very uniform within one and the same codex. At this point, then, our aim is to verify how such regularity, inherent to the pages of a juridical codex, albeit in different ways, is managed in spaces which are significantly close to each other-such as facing and overlying pages-and whether the dynamic that links the non-written and written areas of a page is repeated in the same segments of the adjacent zones.

As part of this set of problems, we can also include the question concerning the treatment of the text/gloss relationship-whether, that is, a strategy aimed at geometric uniformity corresponds to a good level of adjustment in terms of the distance between a passage of text and its relevant gloss.

For each manuscript and incunabulum, the difference between the dimensions of each segment of the written area was calculated for facing and overlying pages, which is to say the difference between segment 1 on the verso/recto and recto/verso pages, and the difference between segment 2 on the verso/recto and recto/verso pages, etc. This was done for both the horizontal and the vertical measurements. Next, the average value for the differences between all the individual segments on facing and overlying pages within all the manuscripts and incunabula was calculated, and finally the average value for the differences observed among all the manuscripts and incunabula.

If one examines Charts 17 and 19, which present the differences between the horizontal measurements on facing and overlying pages, the zones that tend to be afforded greater flexibility are the lateral ones, segments $1 / 2$ and $8 / 9$, which correspond to the margins and the two central branches of the gloss. Once again, the outer zone turns out to be the most non-uniform; on the other hand, the central nucleus maintains great uniformity in all its segments, with the lowest level of variation seen in the intercolumnar zone. It should be noted that the phenomenon manifests itself in a similar way when it comes to facing and overlying pages, even if higher values are seen in the latter.

As for the vertical measurements (see Charts 18 and 20), the greatest irregularities are found in the lower portion of the page, segments VI and VII, which correspond to the final branch of the gloss and the lower margin, followed by the text column, segment VI, and the area corresponding to the upper margin and the first branch of the gloss. The 'moat' is largely speaking uniform, and registers the lowest values. In this case, too, the phenomenon manifests itself in a more pronounced way in the overlying pages. 


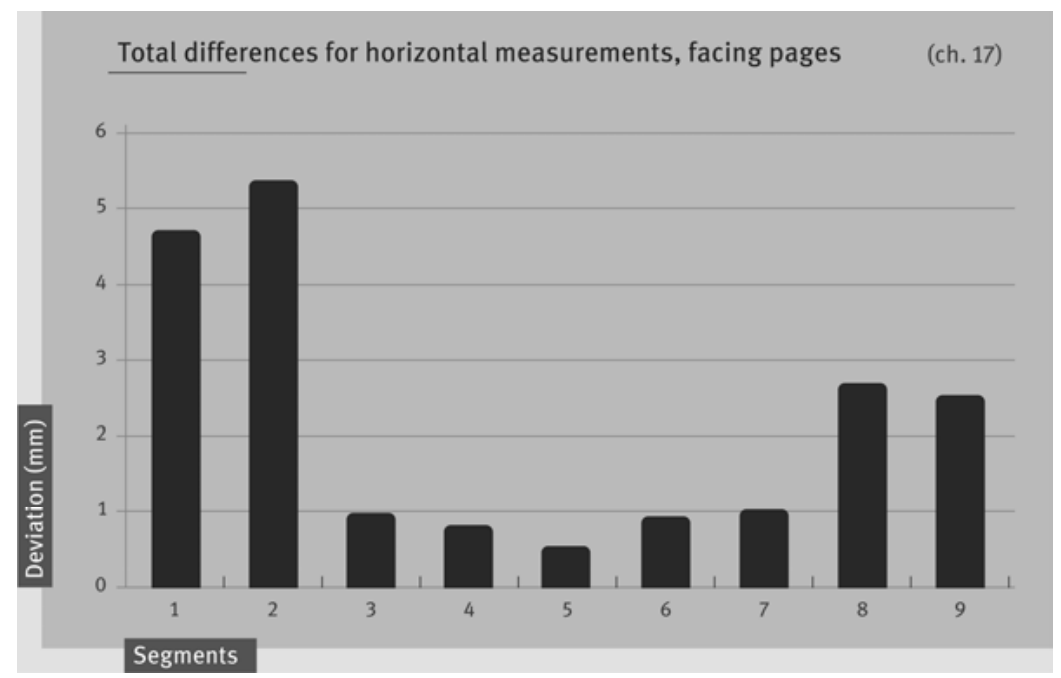

Chart 17: Total differences for horizontal measurements, facing pages

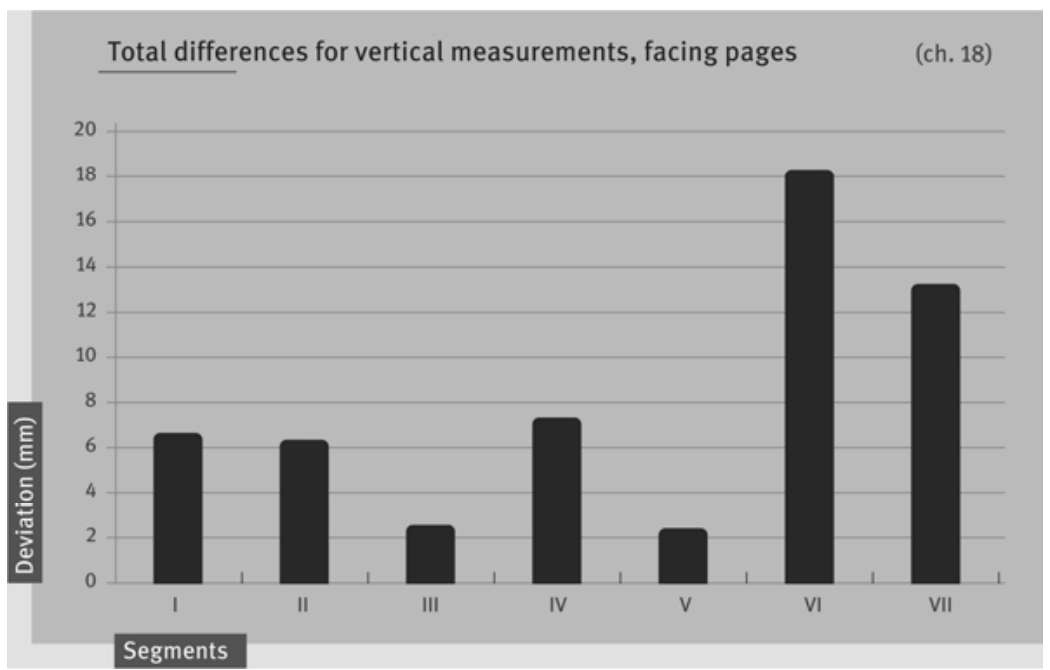

Chart 18: Total differences for vertical measurements, facing pages 


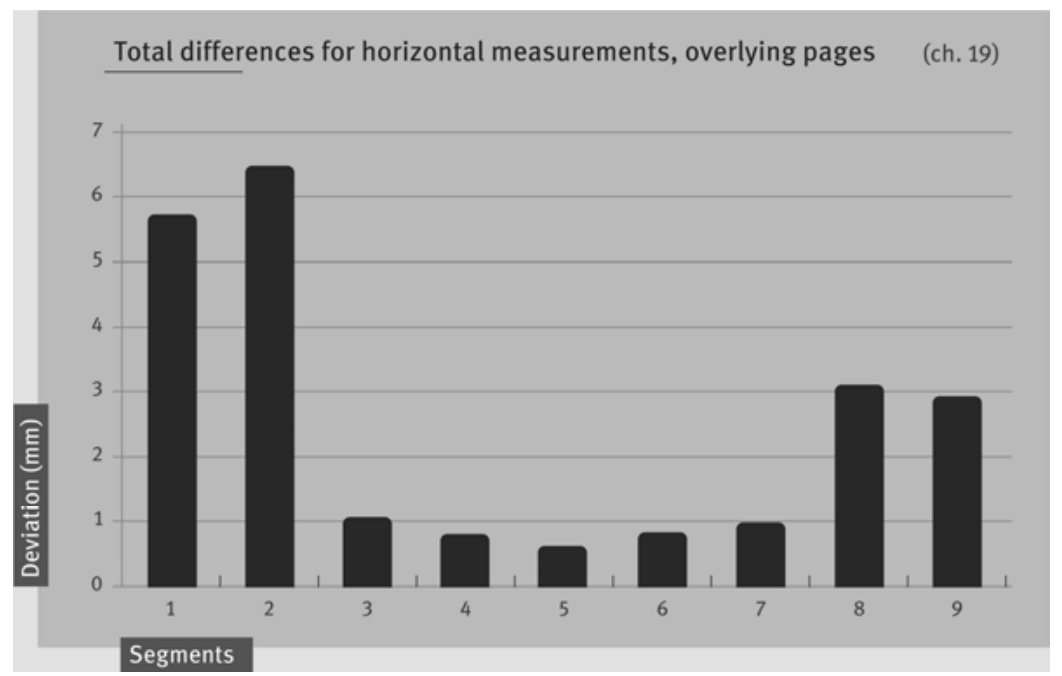

Chart 19: Total differences for horizontal measurements, overlying pages

Generally speaking, then, whether it be for the horizontal or the vertical volumes, the biggest differences are met with along the outer margin, in contrast to a more uniform central nucleus.

The treatment of the overlying pages follows a trend which is identical to that of the facing pages, even if they show higher values. In any event, on balance the highest levels of irregularity are seen along the vertical axis of the page.

At this point it is interesting to see how the phenomenon manifests itself when we distinguish between manuscripts and incunabula (see Charts 21 and 22). 


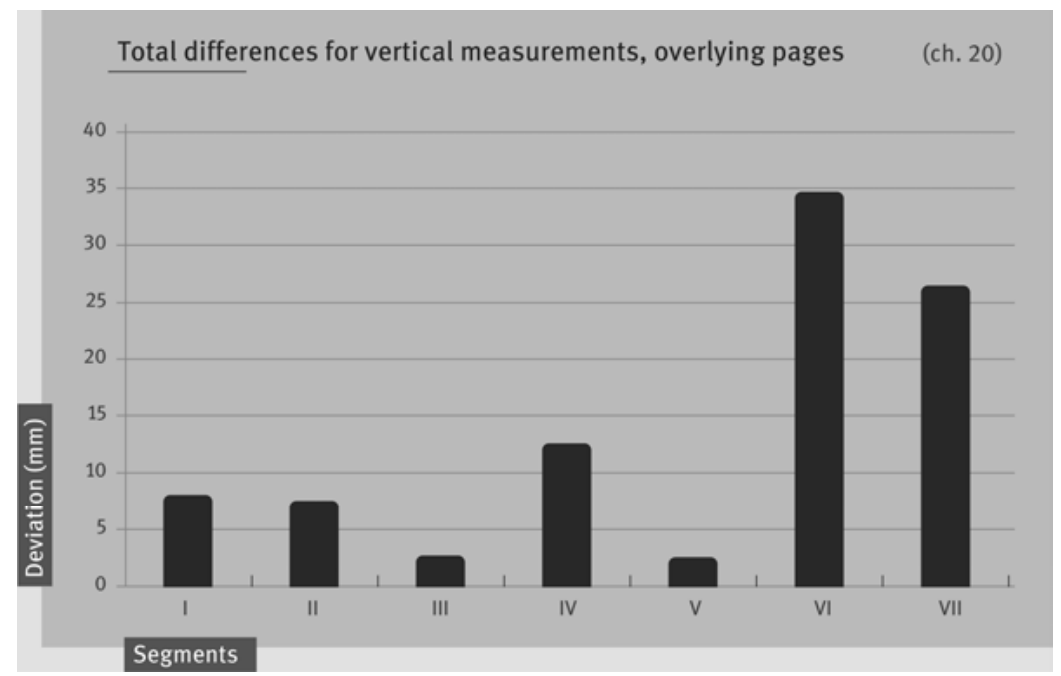

Chart 20: Total differences for vertical measurements, overlying pages

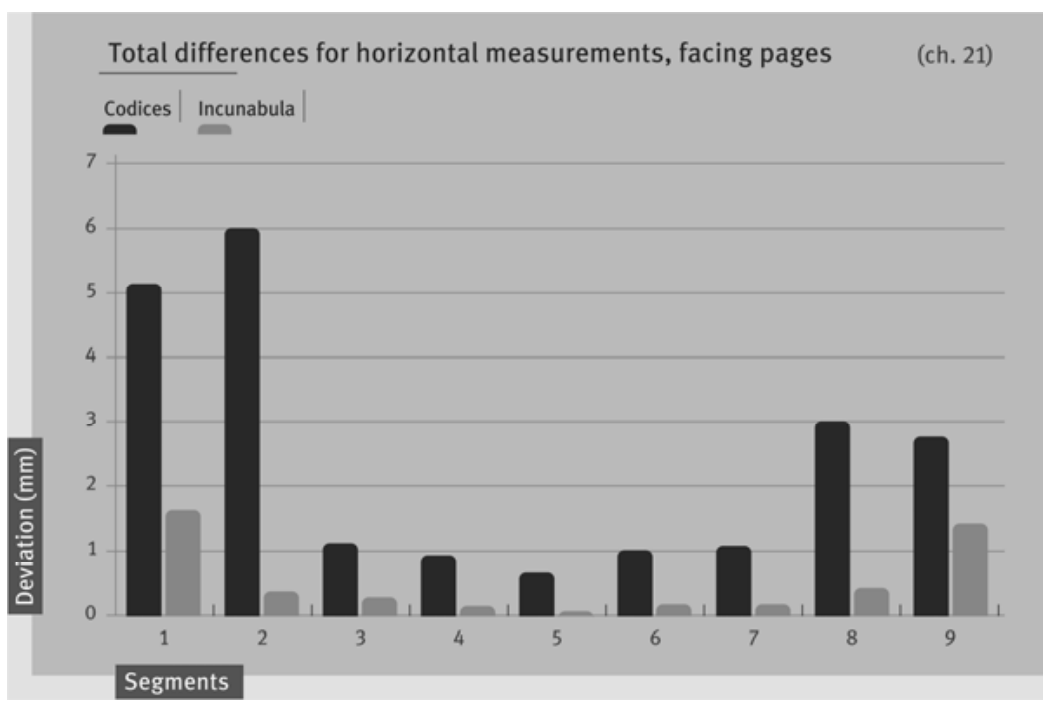

Chart 21: Total differences for horizontal measurements, facing pages

In general, within each manuscript, the facing and overlying pages exhibit a similar trend in their horizontal parts. This represents an indicator of the fact that the lower or higher levels of irregularity in the layout of the text and appa- 
ratus on the page are consistent for the facing and overlying pages in one and the same manuscript. Therefore, the strategy employed for the arrangement of the two text masses on facing pages was evidently the same as that adopted for the overlying pages.

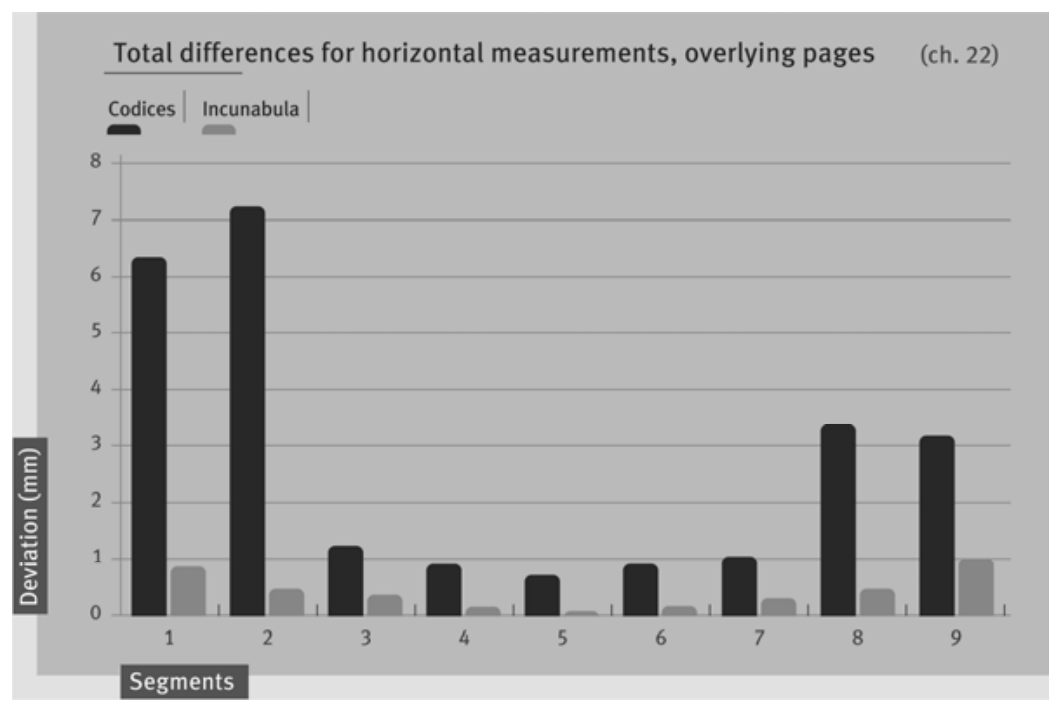

Chart 22: Total differences for horizontal measurements, overlying pages

In the incunabula, this trend proves to be similarly evident: the relationship between volumes, which manifests itself in a less articulated form in comparison to the manuscript, is practically identical in facing and overlying pages.

Conversely, the most important differences can once again be seen along the vertical axis of the page (see Charts 23 and 24). In the manuscripts, the maximum degree of disparity affects the last two volumes, segments VI/VII, which correspond to the final branch of the gloss and the lower margin. This phenomenon, which is very apparent in facing pages, is much more pronounced in overlying ones. In practice, the tendency to exploit and utilise with greater liberty the lower part of the page (by systematically varying the boundary between the gloss and the margin) is applied in a consistent way for the facing pages, and even more so in the overlying ones. 
In the incunabulum, on the other hand, since, as we have already seen, the lower margin remains unchanged, the 'game' shifts to segments IV/VI (i.e. the text column and the final branch of the gloss) in almost identical ways for both the facing and the overlying pages.

The central nucleus of the Bolognese manuscripts mostly conforms to the overall strategies applied in the manuscript, although since the text column, segment IV (see Chart 14), shows greater variability in the overlying pages in the vertical areas, the adjustment mechanism involves not only volumes VI/VII, the final branch of the gloss and the lower margin, but the text column as well.

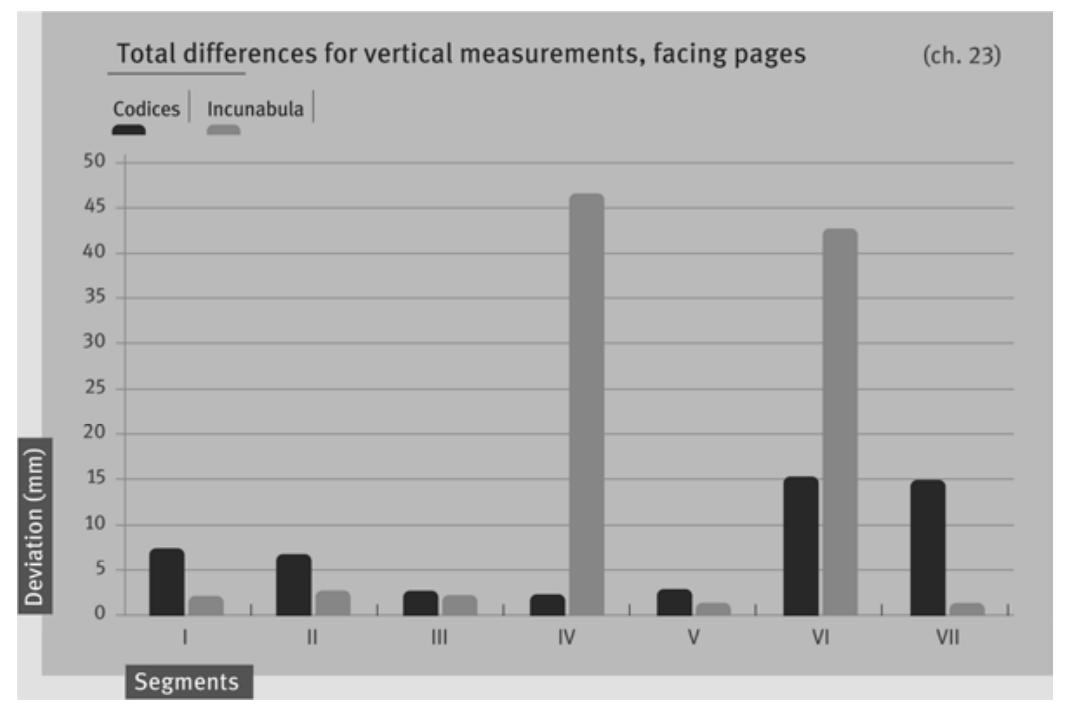

Chart 23: Total differences for vertical measurements, facing pages 


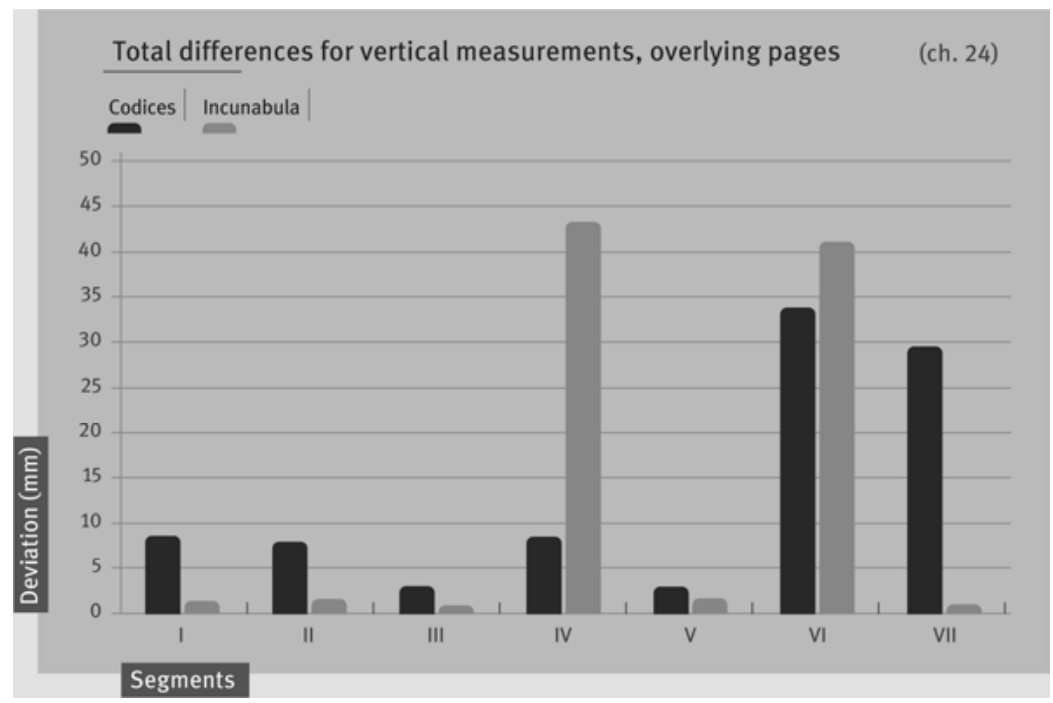

Chart 24: Total differences for vertical measurements, overlying pages

Tab. 4 shows the sum of the differences between the absolute values of all the segments, both horizontal and vertical, of the facing and overlying pages, and indicates the degree of irregularity seen among the various pages.

Sum of the differences between the absolute values of

tab. 4 all the horizontal and vertical segments

\begin{tabular}{|c|c|c|c|}
\hline & All & Codices & Incunabula \\
\hline | Total nr. of facing pages & |103.66 & 104.57 & |96.17 \\
\hline Total nr. of overlying pages & 116.86 & 119.43 & ן95.78 \\
\hline Sum total & 220.51 & 224.00 & | 191.94 \\
\hline Total nr. of horizontal segments/facing pages & 19.70 & $\mathrm{a}^{21.53}$ & $1^{4.65}$ \\
\hline Total nr. of vertical segments/facing pages & 57.15 & |52.04 & ן99.10 \\
\hline | Total nr. of horizontal segments/overlying pages & $\left.\right|^{22.37}$ & $\left.\right|^{24.65}$ & $1^{3.70}$ \\
\hline Total nr. of vertical segments/overlying pages & 94.49 & ן 94.78 & 92.08 \\
\hline | Total nr. of horizontal segments & |79.52 & |76.68 & 102.80 \\
\hline Total $\mathrm{nr}$. of vertical segments & |151.64 & |146.82 & |191.17 \\
\hline
\end{tabular}

Tab. 4: Sum of the differences between the absolute values of all the horizontal and vertical segments 


\subsection{The inner and outer sectors and the text/gloss adjustment in facing and overlying pages}

As a result of this analysis-aimed at examining the framework of the mise en page with respect to the strategies employed for the positioning of each individual segment on facing and overlying pages-a clear tendency has once again emerged to set out a horizontally, and to a slightly lesser extent vertically stable central nucleus, in contrast to more flexible outer and marginal zones.

We shall now focus our attention on these two zones, and therefore shift from a more analytical examination of the individual segments, to an examination of the inner and outer sectors of the page, with a view to identifying the relationship between them. Just as before, the investigation will be carried out on facing and overlying pages.

Given that the inner area, corresponding to segments 3-7 and III-V, contains the text, while the outer one, corresponding to segments $1 / 2 / 8 / 9$ and I/II/VI/VII, is occupied by the gloss, the relationships that exist between the two areas can be associated with the measurements relating to the adjustment of the legal text to the apparatus, which therefore makes it possible to establish the ways in which geometric uniformity strategies and legibility requirements correlate.

If one adds up the values of the differences measured in the segments of the central and outer areas for the facing and overlying pages, it becomes apparent that for both the manuscripts and the incunabula the most striking variations lie within the outer zone of the page, with a greater accentuation in the case of the overlying pages. The inner zone remains stable and follows a trend which is almost identical in both page typologies. This trend, which is more pronounced in the manuscripts, is considerably more limited in the incunabula, where, for example, in facing pages there is almost no difference at all between the central zones (0.84), although an almost imperceptibly higher value is seen in the overlying pages (see Tab. 5). 
Sum of the differences between facing and overlying segments

tab. 5 in the horizontal segments of the central and outer areas

\begin{tabular}{|c|c|c|c|}
\hline & All & Codices & Iratabaisidize \\
\hline | Sum of the diff. between 34,567 facing segments & |4.32 & $1^{4.75}$ & 10.04 \\
\hline |Sum of the diff. between 34,567 overlying segments & $s_{1} 4.27$ & $1^{4.67}$ & 1.00 \\
\hline |Sum of the diff. between 1,289 facing segments & 15.38 & 16.79 & |3.81 \\
\hline |Sum of the diff. between 1,289 overlying segments & | 18.10 & |19.98 & 2.70 \\
\hline |Sum of the diff. between 34,567 segments, total & | 8.59 & |9.42 & 1.84 \\
\hline Sum of the diff. between 1,289 segments, total & 33.48 & 33.76 & 6.51 \\
\hline
\end{tabular}

Tab. 5: Sum of the differences between facing and overlying segments in the horizontal segments of the central and outer areas

The result of the correlation between all the figures relating to the differences between the central and peripheral areas is 0.145 , which indicates the absence of a correlation. This means that where there is uniformity in the central part of the page, it is not necessarily the case that there is a corresponding uniformity in the outer area, and vice versa.

When the correlation function is applied to the values obtained for the differences between the central nucleus in facing and overlying pages $(34,567$ facing; 34,567 overlying) and to the values obtained for the differences between the outer area in the facing and overlying pages (1,289 facing; 1,289 overlying), figures of 0.919 and 0.799 are generated. The two results, which are significantly positive, confirm what has already been ascertained for individual segments on leaves, which means that for the two horizontal areas the same treatment was applied to both facing and overlying pages.

If we now move on to the vertical axis and add up the measurements obtained for the differences between the segments in the central and outer areas of facing and overlying pages, the situation appears to be rather more complex (Tab. 6). 
Sum of the differences between facing and overlying segments

tab. 6

in the vertical segments of the central and outer areas

\begin{tabular}{|c|c|c|c|}
\hline & All & Codices & Incunabula \\
\hline S Sum of the diff. between facing segments III/IV/V & 12.36 & |7.79 & |49.78 \\
\hline |Sum of the diff. between overlying segments III/IV/V & 17.96 & 14.48 & $1^{46.50}$ \\
\hline | Sum of the diff. between facing segments I/II/VI/VII & $1^{44.80}$ & 144.25 & |49.31 \\
\hline | Sum of the diff. between overlying segments I/II/VI/VII & 76.52 & 80.30 & 45.58 \\
\hline Sum of the diff. between segments, total III/IV/V & 30.32 & | 22.27 & |96.28 \\
\hline Sum of the diff. between segments, total I/II/VI/VII & 121.32 & 124.55 & 94.89 \\
\hline
\end{tabular}

Tab. 6: Sum of the differences between facing and overlying segments in the vertical segments of the central and outer areas

In the incunabulum, the phenomenon follows a regular trend in the central and outer zones in both page typologies: in fact, the values range from a minimum of 45.58 to a maximum of 49.78 . This is due to the fact that in the incunabulum the two most variable segments, as we have seen, are the text column and the final branch of the gloss, represented by segments IV/VI. The former belongs to the central nucleus, the latter to the outer zone, and in effect it is precisely these two volumes that generate an overall irregular trend in the pages. In fact, if one calculates the sum of the differences between segments III/V for the facing and overlying pages, and likewise for segments I/II/VII, also for the facing and overlying pages, one obtains values of $6.37,4.13,3.16$ and 2.90, figures which are significantly low and demonstrate, once again, how in the incunabulum the greatest effort to synchronise the text and the gloss was made in the vertical axis in segments IV/VI.

Tab. 6 therefore makes it plain that in the incunabulum there is a calculated and uniform irregularity in the arrangement of the volumes forming the central and outer areas, for both facing and overlying pages.

Conversely, in the manuscripts a generally stable central nucleus on the facing pages, and one which is slightly less so on the overlying pages, is framed by a more 'fluid' outer marginal zone, particularly in the overlying pages, which further demonstrates the role played by segments VI/VII in this respect.

When all the values in relation to the differences between the central and peripheral areas are correlated, the result obtained is -0.125 , which, as for the horizontal direction, demonstrates the absence of a correlation between the two zones of the page. 
When the correlation function is applied along the vertical axis to the values obtained for the differences between the facing and overlying pages in the central nucleus (III/IV/V facing; III/IV/V overlying), and to the values obtained for the differences between the facing and overlying pages in the outer area (I/II/IV/VII facing; I/II/IV/VII overlying), results of 0.484 and 0.479 are obtained. These are positive values, but their significance is not equal to that of those obtained for the horizontal zone of the page. The sector-by-sector analysis also confirms the existence of a greater degree of coordination of volumes along the horizontal axis in comparison to the vertical one.

If the correlation coefficient is no longer applied between the central nucleus and outer zone of the facing and overlying pages, but instead the two areas are cross-correlated, which is to say 3,567 facing with 1,289 facing, 34,567 overlying with 1,289 overlying, III/IV/V facing with I/II/VI/VII facing, III/IV/V overlying with $\mathrm{I} / \mathrm{II} / \mathrm{VI} / \mathrm{VII}$, respectively the values of $0.306,0.284,0.223$ and 0.170 are obtained.

By inserting into a table all the values of the coefficients of correlation obtained by comparing the central and outer zones of facing and overlying pages (Tab. 7), it becomes clear that in practice the techniques employed to achieve uniformity are applied consistently in consecutive leaves, regardless of whether or not they are facing or overlying, and that among consecutive leaves the correlation reaches its maximum when the same areas of pages are evaluated. and outer zones of facing and overlying pages

Tab. 7: Coefficients of correlation obtained by comparing the central and outer zones of facing and overlying pages 
Returning to the vertical axis, we have seen how the volumes belonging to the central nucleus and outer areas of the page are somewhat different. By comparing the variability of the inner (III/IV/V) and outer (I/II/VI/VII) vertical segments, it has been possible to identify a series of techniques or strategies aimed at regulating the degree of geometric uniformity/diversity in the arrangement of the two written units. In order to calculate the distribution of the strategies employed in the sample corpus, the absolute values of all the variations in all the vertical segments were added up, for both the facing and the overlying pages. Next, for each type of page, the values obtained for the inner and outer zones were compared. If the values arrived at for the facing and overlying pages are below 40-50, this equates to a $u$ (uniformity) strategy, which is to say consistency between facing and overlying pages. If, on the other hand, the value for the facing pages is below this figure and that of the overlying ones exceeds it, one can speak of an $r$ (regularity) strategy, which is to say regularity in the composition of the former and irregularity in the latter. If, however, both exceed a value of 40/50, an $i$ (irregularity) strategy can be spoken of, which is to say irregularity in both facing and overlying pages.

The distribution of the strategies within the sample is shown in Tab. 8 and 9.

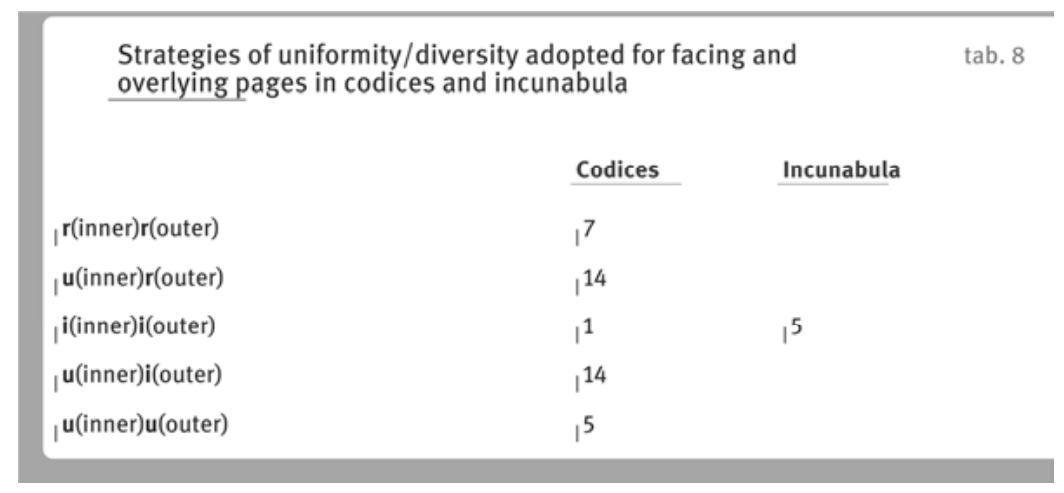

Tab. 8: Strategies of uniformity/diversity adopted for facing and overlying pages in codices and incunabula 


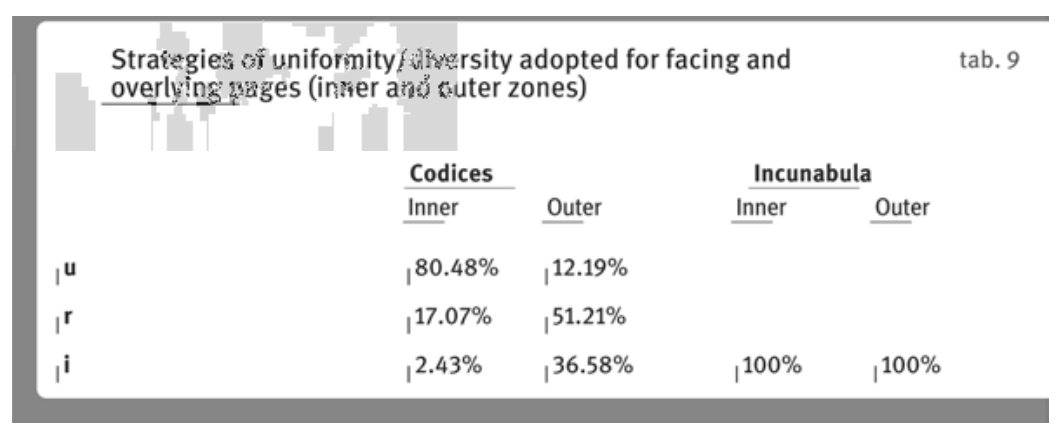

Tab. 9: Strategies of uniformity/diversity adopted for facing and overlying pages (inner and outer zones)

By assigning numerical values to the different couplings of strategies identified in the sample, namely $1=u$ (inner) $u$ (outer), $2=u$ (inner) $r$ (outer), $3=r$ (inner) $r$ (outer), $4=u$ (inner) $i$ (outer), $5=i$ (inner) $i$ (outer), it becomes possible to compare these data with those relating to the adjustment of the text/gloss.

For this part of the investigation the survey was carried out within a specific quire containing a specific passage from the Codex. The passage concerned is composed of approximately 500 words ${ }^{60}$ and is drawn from liber III, titulus I (de iudiciis), lex 30 , paragraphi $1-2 .{ }^{61}$ To adjust one passage of the gloss to the corresponding lemma in the text a numeric value, based on certain modalities, is assigned to the distance between the two parameters. These values depend on the area of the page where the text and apparatus are positioned. Fig. 6 and 7 represent two pages of an open codex; to the left we see the verso leaf, to the right the recto.

60 The count was carried out on a printed edition of the Corpus Iuris Civilis.

61 The selection of this passage from Justinian's Codex was not purely random, given that the objective was to be able to have at one's disposable a sufficiently long piece of text, and one which comprised the beginning of a book and all its most important hierarchical subdivisions, including the title, the law and the clause. 
Survey of the distance between text and apparatus in two pages of an open codex

6

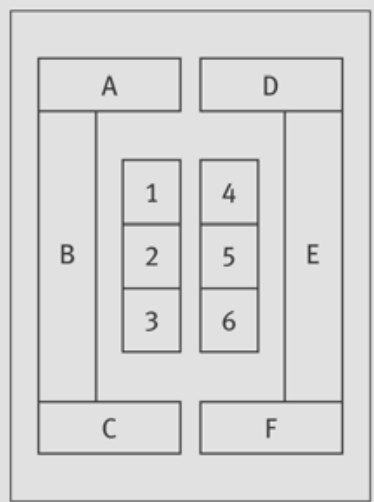

Recto
7

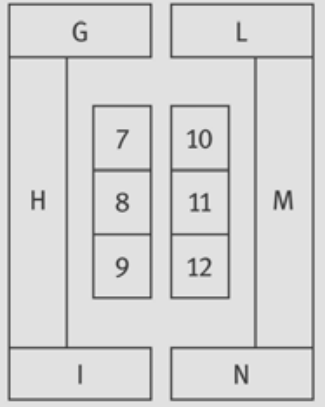

Verso

Fig. 6-7: Survey of the distance between text and apparatus in two pages of an open codex

The columns containing the text have been divided into three sections. Likewise, the gloss has been divided into the usual three branches. If the first glossed lemma of the pre-selected text is located in section 1 and the corresponding gloss in sector $A$, the numerical value assigned is 0 ; if the gloss is positioned in $\mathrm{B}$, the value is 1 ; if the gloss is in $\mathrm{C}$, the value is 2 ; if the gloss is in $\mathrm{D}$, the value is 4 , and so on. If, on the other hand, the text commences in section 2, the mechanism is identical, but the 'slippage' (i.e. asynchrony) of a block is factored into the evaluation. Thus, if the text is located in section 2 and the gloss in sector $A$, the numerical value assigned is 1 ; if the gloss is in $B$, the value is 0 ; if the gloss is in $C$, the value is 1 ; if the gloss is in $D$, the value is 2 , and so on. With the transition from a verso leaf to a recto leaf a penalty of 3 points is envisaged, hence if the text commences in sector 1 and the gloss is found in $G$, the score is 9. Conversely, the transition from the recto to the verso of a leaf results in a penalty of 6 points, hence if the text (once again) commences in sector 1 but the corresponding text is located in sector A on the verso of the successive leaf, the score is $20 .^{62}$

62 Tab. 9a shows the results of all the possible combinations contained within two pages (recto/verso). 
The results of all possible combinations contained

within two pages (recto/verso)

\begin{tabular}{|c|c|c|c|c|c|c|c|c|c|c|c|c|}
\hline & $\left.\right|^{\mathbf{A}}$ & $\left.\right|^{B}$ & ${ }_{1} \mathrm{C}$ & D & $\left.\right|^{E}$ & ${ }_{1} \mathbf{F}$ & ${ }_{1}^{\mathbf{G}}$ & ${ }_{1} \mathrm{H}$ & اן & ${ }^{L} \mathbf{L}$ & ${ }_{1} \mathbf{M}$ & ${ }^{\mathrm{N}}$ \\
\hline$\left.\right|^{1}$ & $1^{0}$ & $\left.\right|^{1}$ & $\left.\right|^{2}$ & $1^{3}$ & $1^{4}$ & $1^{5}$ & 9 & |10 & |11 & |12 & 13 & |14 \\
\hline $1^{2}$ & $\left.\right|^{1}$ & ${ }^{0} 0$ & $\left.\right|^{1}$ & $1^{2}$ & $1^{3}$ & $1^{4}$ & 8 & 9 & |10 & |11 & |12 & $\left.\right|^{13}$ \\
\hline $1^{3}$ & $1^{2}$ & $\left.\right|^{1}$ & $1^{0}$ & $\left.\right|^{1}$ & $1^{2}$ & $1^{3}$ & $\mathrm{I}^{7}$ & 8 & 9 & $\left.\right|^{10}$ & |11 & $\left.\right|^{12}$ \\
\hline $1^{4}$ & $1^{3}$ & $1^{2}$ & $\left.\right|^{1}$ & 0 & $\left.\right|^{1}$ & $1^{2}$ & $1^{6}$ & $1^{7}$ & 8 & 9 & |10 & |11 \\
\hline $1^{5}$ & $1^{4}$ & $1^{3}$ & $1^{2}$ & $\left.\right|^{1}$ & $1^{0}$ & $\left.\right|^{1}$ & $1^{5}$ & 6 & $\left.\right|^{7}$ & 8 & |9 & |10 \\
\hline , 6 & $1^{5}$ & $1^{4}$ & $1^{3}$ & $1^{2}$ & $\left.\right|^{1}$ & $1^{0}$ & $1^{4}$ & $1^{5}$ & $1^{6}$ & $1^{7}$ & 8 & 9 \\
\hline$\left.\right|^{7}$ & 9 & 8 & $1^{7}$ & $1^{6}$ & $1^{5}$ & $1^{4}$ & $1^{0}$ & $\left.\right|^{1}$ & $1^{2}$ & $1^{3}$ & $1^{4}$ & $1^{5}$ \\
\hline 8 & |10 & 9 & 8 & $\left.\right|^{7}$ & $1^{6}$ & $1^{5}$ & $\left.\right|^{1}$ & । 0 & $\left.\right|^{1}$ & $1^{2}$ & $1^{3}$ & $1^{4}$ \\
\hline 9ן & $\left.\right|^{11}$ & |10 & 9 & 8 & $1^{7}$ & $1^{6}$ & $1^{2}$ & $\left.\right|^{1}$ & $।^{0}$ & $\left.\right|^{1}$ & $1^{2}$ & $1^{3}$ \\
\hline 10 & |12 & |11 & |10 & 9 & 8 & $1^{7}$ & $1^{3}$ & $1^{2}$ & $\left.\right|^{1}$ & $1^{0}$ & $\left.\right|^{1}$ & $1^{2}$ \\
\hline |11 & |13 & $\left.\right|^{12}$ & |11 & |10 & $1^{9}$ & $\left.\right|^{8}$ & $1^{4}$ & $1^{3}$ & $1^{2}$ & $\left.\right|^{1}$ & $।^{0}$ & $\left.\right|^{1}$ \\
\hline |12 & $\left.\right|^{14}$ & |13 & $\left.\right|^{12}$ & $\left.\right|^{11}$ & |10 & $\left.\right|^{9}$ & $1^{5}$ & $1^{4}$ & $1^{3}$ & $1^{2}$ & $\left.\right|^{1}$ & $\left.\right|^{0}$ \\
\hline
\end{tabular}

Tab. 9a: The results of all possible combinations contained within two pages (recto/verso)

In the manuscripts the average is 2.23 , whereas in the incunabula it is 0.77 : this means that in the manuscripts the distance covers roughly two sectors of the page, whilst in the incunabula the distance covered is less than one sector. Legibility, promoted by a better synchronisation of the text to the relevant gloss, therefore proves to be far superior in the incunabulum in comparison to the manuscript.

If one compares the values of the uniformity strategies with those of the text/gloss adjustment, a negative situation emerges for both book typologies. In the manuscript the correlation result is -0.480 , which suggests a conflict between the need for geometric regularity in the distribution of volumes on the page and the legibility requirement.

In the incunabulum the conflict is even greater; this can immediately be apprehended from the average values by means of which the two phenomena 
manifest themselves. ${ }^{63}$ In practice, in the incunabulum we find ourselves looking at two extreme solutions represented by the values 0.77 for the displacement of the text/gloss and 5 for the uniformity strategies. The former requires greater attention being paid to legibility, whilst the latter corresponds, as the reader will recall, to the ii strategy, which is to say a situation characterised by maximum irregularity.

Therefore, even if the two phenomena are generally seen in opposition in the manuscript and incunabulum, it is in the latter that the contrast is more pronounced.

The overall picture is summarised in Tab. 10, where the average values with respect to 'slippage' in relation to hierarchical type are presented.

Average value of 'slippage' in relation to hierarchical type

tab. 10

\begin{tabular}{|c|c|}
\hline Hierarchical type & 'Average slippage' \\
\hline$\left.\right|^{1(u u)}$ & |5.16 \\
\hline $1^{2}$ (ur) & |2.89 \\
\hline $1^{3(r r)}$ & 1.67 \\
\hline $1^{4}$ (ui) & 1.33 \\
\hline 5 (ii) & 0.79 \\
\hline
\end{tabular}

Tab. 10: Average value of 'slippage' in relation to hierarchical type

The inversely proportional relationship that links the tendency towards regularity with superior legibility is plain to see. Those who favoured consistent uniformity between the inner and outer parts of facing pages paid the price for this when it came to the degree of text/gloss adjustment, and vice versa. The intermediate and qualitatively better solution is represented by a page facing technique that succeeds in balancing the two phenomena.

We have already seen how the Bolognese codices occupy, in some respects, an intermediate position among the incunabula and the other manuscripts. It

63 In fact, from a mathematical perspective, in the incunabulum it is not possible to calculate the coefficient of correlation between the uniformity strategy and the need for legibility, since the first of the two phenomena always has a value of 5 , and hence a variability of 0 . 
will be interesting to see whether it is also true that in the text/gloss adjustment phenomenon they also reflect this tendency.

For the Bolognese manuscripts, the average value for text/gloss 'slippage' is 1.09 , whereas in all the other manuscripts the average is 2.80 . This means that if in the former the distance covers almost one sector of the written page, in the latter it extends across three sectors. Since, on the other hand, the 'slippage' value in relation to the hierarchy type is 2.93 for the Bolognese manuscripts and 2.74 for all the others, in practice the Bolognese manuscripts, despite maintaining a hierarchy equal to that of the other manuscripts-corresponding for the most part with Type 2 (ur)-present a good level of adjustment between the text and gloss.

\section{Text/gloss adjustment within the inner zone of the page}

The investigation carried out so far on the distribution of the volumes that make up the text, gloss and blank spaces on the page has made use of measurements taken of the written area which, as the reader will recall, were obtained by means of a specific methodological strategy.

Measurement of the vertical axis of the page was carried out once only, on either column a or column $\mathrm{b}$, which for branches $\mathrm{A}$ and $\mathrm{C}$ of the gloss presented with a greater number of lines, and was therefore of larger size.

The data obtained in this way made it possible to analyse the construction techniques employed in the layout of the page in all the segments of the written area in relation to size, variability and correlation within each book typology, and among all the manuscripts and incunabula. The focus was then shifted to the strategies adopted for the same segments in facing and overlying pages, and it was observed how the different solutions employed to foster a greater or lesser degree of regularity of the two text masses on the page relate to the different text/gloss adjustment procedures.

However, the measurements taken of the written area did not make it possible to examine the relationship between the two sectors-left and right-on one and the same page. This is due a lack of values with respect to columns $a$ and $b$, relating to the lower and upper branches of the gloss.

This setback was overcome by making use of data relating to the number of lines in the apparatus on the page. The relevant data was obtained for each of the text columns and the three branches of the gloss, distinguishing between column $a$ and column $b$. 
In any event, the analysis that follows will only refer to sectors $\mathrm{A}$ and $\mathrm{C}$ of columns a and $b$, given that the size of branch $B$, despite varying in the number of lines it contains, is always furnished by the sum of the measurements of segments III/IV/V, whereas the number of lines within the two columns of text is always the same on any page.

Tab. 11 presents the average values of the differences in the number of lines in branches $\mathrm{A}$ and $\mathrm{C}$ of the gloss within the two columns. ${ }^{64}$

In the incunabulum, the difference is minimal in all cases; indeed, it effectively equates to less than one line.

Differences in the number of lines in branches

tab. 11

$A$ and $C$ of the gloss (columns $a$ and $b$ )

\begin{tabular}{|c|c|c|c|}
\hline & All & Codices & Incunabula \\
\hline Diff. zone A col. $a / b$ & 0.87 & 0.97 & 0.01 \\
\hline Diff. zone C col. $a / b$ & 1.44 & 1.52 & 0.78 \\
\hline Diff. zone $\mathrm{A}+\mathrm{C}$ col. $a / b$ & 2.30 & 2.49 & 0.79 \\
\hline
\end{tabular}

Tab. 11: Differences in the number of lines in branches $A$ and $C$ of the gloss (columns $a$ and $b$ )

In the manuscript, a larger, even if not very great, difference between the two branches is seen. As usual, this is noticeable above all in the most variable lower zone of the page: the difference, in fact, is of one and a half lines.

Tab. 12 presents the figures obtained from the calculation of the average difference in the number of lines between the two branches of the gloss in the facing and overlying pages.

64 The difference in the number of lines contained in the two branches of the gloss was calculated as an absolute value. 
Difference in the number of lines between the two

tab. 12

branches of the gloss in facing and overlying pages

\begin{tabular}{|c|c|c|c|}
\hline Diff. in number of lines & All & Codices & Incunabula \\
\hline Facing zone A col. $a / b$ & 1.68 & 1.89 & 0.00 \\
\hline Overlying zone A col. $a / b$ & 1.54 & |1.72 & 0.01 \\
\hline Facing zone $\mathrm{C}$ col. $a / b$ & 2.75 & 2.86 & 1.78 \\
\hline Overlying zone $C$ col. $a / b$ & 2.74 & 2.88 & 1.57 \\
\hline
\end{tabular}

Tab. 12: Difference in the number of lines between the two branches of the gloss in facing and overlying pages

The first thing to note is the rather marked difference between the two branches, $\mathrm{A}$ and $\mathrm{C}$, of the gloss. In the manuscript, in the upper part of the page there is a difference of almost two lines, whereas in the incunabulum there is no difference at all. As regards the lower area, the variation is roughly three lines and one and a half lines, respectively. This trend is at any rate consistent in both the facing and the underlying pages.

These data provide further confirmation of, and partly explain what has already been said about the shifting of volumes on the surface of a page. Even if the lower area of the page proves to be the most variable, the differing degrees of variability are not always found in the same sectors of the page, but rather in different ones, which, as the reader will recall, correspond to segments VI/VII in the manuscript and segments IV/VI in the incunabulum.

Now we shall try to compare the variability of the number of lines with the various other strategies used to regularise the volumes, identified by the initials $u, i$ and $r$ (see above), in the inner and outer zones on the vertical axis of a page. As we have already seen, the most qualitatively significant strategy was represented by type $r r$, an approach that resulted in perfect uniformity in the outer and inner areas of facing pages, and which achieved a good degree of text/gloss synchrony.

The comparison we plan to make requires that we calculate the average difference in the number of lines contained in branches $\mathrm{A}$ and $\mathrm{C}$ of the gloss in relation to the various strategies employed. With this goal in mind, four strategy classes have been identified. The first strategy includes the manuscripts in which at least one page facing option was employed, $u r$ and $r$; the second and third strategies include the manuscripts in which a complete facing op- 
tion was employed, $r$, or a partial one, ur; finally, the fourth class includes all the strategies where no facing technique was employed, i.e. $u i, i i, u u$.

By studying the results presented in Table 13, one can see that when facing is complete, the difference in the number of lines is lower. In any event, even a partial facing option always results in a certain degree of uniformity. On the other hand, the greatest variation is found in all the strategies that represent alternatives to the facing option. Finally, it should be noted that, as a rule, the values for zone A are always proportionately lower than those of zone C.

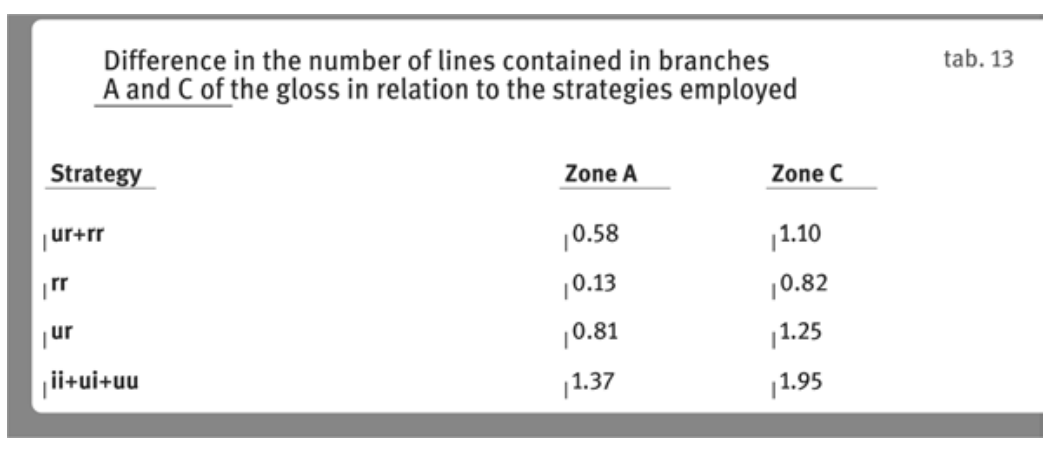

Tab. 13: Difference in the number of lines contained in branches $A$ and $C$ of the gloss in relation to the strategies employed

The treatment reserved for facing and overlying pages is almost identical. The greater or lesser degree of uniformity adopted for the two external branches of the gloss in relation to the various strategies manifests itself in a consistent way on consecutive pages and shows, as usual, higher values in area $\mathrm{C}$ of the gloss (Tab. 14).

The differences in facing between the two branches of the gloss indicate the extent of the variability of two written areas-separate from the main textwhich are markedly flexible within the boundaries of the page. 
Difference in the number of lines contained in branches $A$ and $C$ of the gloss according to the different strategies, in facing and overlying pages

\begin{tabular}{|c|c|c|c|c|}
\hline & ur+rr & $\mathrm{rr}$ & ur & $\underline{i i+u i+u u}$ \\
\hline | Diff. between facing pages, zone A col. $a / b$ & 1.0 & 0.15 & 1.42 & $\left.\right|^{2.78}$ \\
\hline । Diff. between overlying pages, zone A col. $a / b$ & 1.04 & 0.24 & 1.44 & $1^{2.42}$ \\
\hline Diff. between facing pages, zone $\mathrm{C}$ col. $a / b$ & 2.05 & 1.75 & 2.20 & |3.67 \\
\hline | Diff. between overlying pages, zone $\mathrm{C}$ col. $a / b$ & $1^{2.03}$ & 1.64 & 2.23 & 3.74 \\
\hline
\end{tabular}

Tab. 14: Difference in the number of lines contained in branches $A$ and $C$ of the gloss according to the different strategies, in facing and overlying pages

This phenomenon can be helpful when carrying out a more specific and detailed analysis of the relationship between the technique used to achieve uniformity and the need for legibility, since it allows one to correlate the text/apparatus displacement values with a gloss mobility index that refers to one and the same page.

The procedure consists in calculating the coefficient of correlation between the variations in the number of lines in the two branches of the gloss and the text/gloss displacement values: for the incunabulum, the result produced is 0.697, whereas for the manuscript it is -0.096 .

In the first case, we are confronted by a contradictory situation, since, as the reader will no doubt recall, in the incunabula there exists a clear conflict between uniformity and the need for legibility-a conflict which is plain to see between the type of strategy with the highest value, 5 (ii), and the lowest value for the text/gloss adjustment, 0.77. However, based on the result of the correlation, the page appears to be in a state of positive equilibrium, because the uniformity in the outer volumes of the gloss corresponds to the attention paid to the legibility factor. What, then, does this discordance between the central part of an incunabulum and a page of the same book depend on?

The conflict can in fact readily be resolved if one views the problem from a practical viewpoint, focusing attention on how, in material terms, a law book equipped with an apparatus was fabricated. Needless to say, different techniques, such as printing in the case of the incunabulum and copying by hand in the case of the manuscript, have to be taken into consideration. 
Thanks to important technical innovations, starting in around $1473^{65}$ the printing of surfaces corresponding to entire sheets began. The composition of the two text masses was carried out on concordant and non-concordant pages, according to the natural sequence of the text. This necessitated a prior simultaneous arrangement of the text and gloss. Consequently, the adjustment on the page of the main juridical text to the apparatus was planned in advance. This represented what we can define as the 'adjustment unit' or 'adjustment index' ${ }^{66}$

In practice, the calibration of the text was carried out in such a way so as to vary its length in relation to the size of the gloss. Because a predetermined amount of apparatus had to be inserted, in the incunabulum the geometry of the glossed area was given precedence. In fact, asymmetry in the branches of the gloss is, as we have seen, minimal, despite the adjustment being kept at an optimal level (usually, in less than one block). Hence, a check was kept on any displacement by occasionally calibrating the columns of text to the gloss volumes located in the lower part of the leaf (segments IV and VI). In the incunabulum, then, the adjustment index was embodied by the surface of the page.

By contrast, in the case of a manuscript a different situation is observed. If, within a codex, a conflict between uniformity strategies and the need for legibility has emerged -the coefficient of correlation is in fact - 0.480 -the same coefficient for a page is, as we have seen, -0.096 , which indicates the absence of a correlation.

The fundamental difference with respect to the incunabulum lies in the fact that in the manuscript the transcription of the juridical text and gloss was carried out in accordance with the natural sequence of the text. Additionally, the adaptation of the gloss, within a specific amount of text, was dependent upon both the number of lemmata to gloss and the length of the commentary corresponding to each individual passage.

When a scribe was preparing to copy a juridical work equipped with an apparatus, we can surmise that he found himself confronted by two possibilities: (a) the manuscript already contained the text, or (b) he would have to realise both the text and the gloss. ${ }^{67}$ In both cases, it is quite likely that from the outset he endeavoured to pay attention to the text/gloss adjustment and therefore tried to calibrate the two text masses as closely as possible.

65 See footnote 37.

66 Here, the term 'unit of adjustment' is intended to mean the amount of space represented by text or material space on the writing support in which the scribe sought to remedy any displacement (i.e. 'slippage') he encountered.

67 In effect, this characteristic is common to all the manuscripts within the corpus, both those in which the writing of the text and of the apparatus were carried out contemporaneously, and those in which the two operations were carried out at different times. 
If, for various reasons, during the writing process displacement phenomena were encountered, several corrective measures could be employed to compensate for the variance. Given that this process followed the sequential succession of the text, such measures could only be predetermined up to a certain point. In addition, an unplanned adjustment could never be performed completely 'off the cuff', as it were.

It becomes clear, then, that the correction mechanism that favoured a superior adaptation of the text and gloss could be deployed at any point in the manuscript where the situation rendered it necessary.

The fact that no correlation exists $(-0.096)$ between the displacement and uniformity of the outer volumes of a page, whereas the same correlation is negative (0.489) in the inner part of the manuscript, indicates that even if in the codex, taken overall, symmetry and legibility strategies conflict, the material adjustment unit upon which this mechanism is based in the manuscript is not the page. ${ }^{68}$

Current research does not permit further investigation of this issue, since the text/gloss measurements carried out on a single passage of Justinian's Codex, despite being adequate for the incunabulum, proved to be insufficient in the case of the manuscript.

In the manuscript, the adjustment of the juridical text to the apparatus was carried out according to particularly complex 'rhythms' and schemes, and therefore specific surveying procedures are necessary for the collection of data.

To achieve this end, a number of factors should be borne in mind. Several different recensions of Accursius's ordinary gloss can be linked to the nine text units which correlate to the division into nine books of the Codex. Therefore, a preliminary selection should be made on the basis of the apparatus, the objective being to assemble groups of manuscripts equipped with almost identically developed glosses. Next, the reproduction mechanisms used in the production of the Corpus Iuris Civilis cannot be disregarded, since these were based on models-the exemplaria-that were composed of loose quires, which in turn were subdivided internally into peciae. In addition, the exemplaria of the text and glosses circulated separately, which undoubtedly made it more difficult to link them on a page. ${ }^{69} \mathrm{~A}$ preliminary analysis of the text/gloss displacement (i.e. 'slippage') could start out

68 A different method is employed for surveying the text/gloss displacement in the manuscript. Instead of being limited to just one passage of text, the survey is carried out at different points, though not at selected at random, throughout the entire codex.

69 Above all in the Bolognese manuscripts, where at the time of manufacture a good synchronisation of the text and gloss was achieved (see above). 
from manuscripts bearing pecia marks; then a specific passage to survey could be selected from within a length of text contained between two pecia marks.

This procedure should be carried out on multiple segments of manuscript, distributed, if possible, within individual volumes. The passages selected would then constitute the benchmark models to refer to when surveying manuscripts lacking pecia marks.

Some other procedures based on material rather than textual criteria could be combined with those outlined above. These would consist in gathering a random series of data from within a specific number of whole or half quires in the manuscript.

The two methods combined could provide valuable clues on the strategies employed by the copyists to synchronise the gloss with the text. In addition, this approach may on occasion make it possible to identify the key space on the page or the juncture when this operation, which we have termed the unit of adjustment, was carried out.

From this initial investigation of various manuscript and printed volumes containing Justinian's Codex with glosses, some important information on the techniques and strategies adopted in the two book types for the shaping and organisation of a fixed amount of text in relation to the available space has emerged. In our view, the first important observation to make is that it impossible to draw a clear distinction between the manuscript and the incunabulum, since the solutions employed by artisans in the $13^{\text {th }}$ to $14^{\text {th }}$ centuries, and by printers in the $15^{\text {th }}$, despite resulting in differences in, for example, the management of the various sectors of the page, or the composition of the text with gloss, cannot be seen as being entirely at odds with each other. An underlying distinctiveness exists in the concept and type of product that was made, but clearly not in the means and forms that were very closely bound to the two different production contexts. The reason for this continuity that accompanied the shift from a manual fabrication technique to a mechanical one essentially lies in the strength and prestige of a book-the law tome-which was still regarded as being functional in the system and structure that a centuries-old tradition had established. To these, other factors that cannot be disregarded, and which likewise became consolidated over time, must be added, namely the manuscript's aesthetic bearing and trends in taste that only with difficulty the printed book could have countered. In general, then, the image for the juridical book that the world of the manuscript proposed was largely inherited by that of the printed book, even if not in a purely and simply imitative form. In fact, a page in an incunabulum containing Justinian's Codex does not constitute a 'photographic' reproduction of a manuscript page bearing the same passage of text. Nevertheless, both were planned in the same 
way, and within them all the written and non-written sectors follow the same design. In what way, then, do they differ? The difference essentially lies in the relationship which is set up between these elements in terms of hierarchy and proportionality, and therefore the mechanisms that regulate and govern the composition of the two textual units-i.e. the main text and the gloss-in an effort to strike a difficult balance between the functional need for legibility and an aesthetic principle, namely visual uniformity and homogeneity. More than once during the course of this investigation reference has been made to the decisive role played by different production methods in determining a certain kind of strategy, and therefore to how a manual production process (contingent on the pace of the copying of the exemplar into quires) and a mechanical one inevitably exert an influence on the structure of the book and the ways in which the graphical component was placed in the space it was destined for. It is rather obvious, and perhaps unnecessary, to remind ourselves that the advent of printing represented a drastic material and economic departure from the age of the manuscript; on the other hand, it is also true that this revolution 'tout en améliorant d'une manière décisive le bilan énergétique global du système de production, ne peut-elle que déséquilibrer la repartition des coûts et engendrer ainsi de nouvelles contradictions'. ${ }^{70}$ Notwithstanding the specificity of the two production contexts and the unquestionable advantages that accompanied the advent of printing, what we have been able to confirm here, by examining the various phenomena, is the extent to which the standards applied in manuscript production, with respect to specific aesthetic and functional demands, coincide with those used for the incunabulum, and the degree to which tradition and innovation coexist.

\section{References}

Astuti, Guido (1968), 'La “glossa accursiana”, In Rossi, Guido (ed.), Atti del convegno internazionale di studi accursiani. Bologna 21-26 octobre 1963, Milano: Giuffrè, 289-379.

Astuti, Guido (1968a), Lezione di storia del diritto italiano. Le fonti. Età romano-barbarica, Padova: CEDAM.

Avril, François / Gousset, Marie-Thérèse (1984), Manuscrits enluminés d'origine italienne, II. XIII siècle, Paris: Centre de recherche sur les manuscrits enluminés, Bibliothèque nationale (Manuscrits enluminés de la Bibliothèque nationale de France).

Balsamo, Luigi (1988), 'Editoria a Bologna nei secoli XV-XVIII', in Alma mater studiorum. Nove secoli di editoria bolognese per l'Università, Bologna: CLUEB, 74-76.

70 Ornato 1994, 18-19. 
Bataillon et al. (1988), 'La production du livre universitaire au moyen âge : Exemplar et pecia'. Actes du symposium tenu au Collegio San Bonaventura de Grottaferrata en mai 1983, Paris: C.N.R.S.

Bellomo, Manlio (1988), Saggio sull'università nell'età del diritto comune, Catania: Giannotta. Bozzolo, Carla / Ornato, Ezio (1980), Pour une histoire du livre manuscrit au Moyen Âge. Trois essais de codicologie quantitative, Paris: CNRS (Publications de l'équipe de recherche sur l'humanisme français des XIV et $\mathrm{XV}^{\mathrm{e}}$ siècles. Textes et études, 2).

Bozzolo, Carla / Ornato, Ezio (1982), 'Pour une codicologie “expérimentale”, in Scrittura e civiltà, 6: 263-302 (repr. in [Ornato, Ezio et al.] [1997], La face cachée du livre médiéval. L'histoire du livre vue par Ezio Ornato, ses amis et ses collègues. Avec une préface d'Armando Petrucci, Roma; Viella [I libri di Viella, 10], 3-31).

Bozzolo, Carla / Ornato, Ezio (1986), 'L'étude quantitative du manuscrit médiéval : aspects méthodologiques et perspectives de recherche', in Härtel, Helmar (ed.), Probleme der Bearbeitung mittelalterlicher Handschriften, Wiesbaden: Harrassowitz (Wolfenbütteler Forschungen 30), 233-239.

Bozzolo, Carla / Coq, Dominique / Muzerelle, Denis / Ornato, Ezio (1984), 'Noir et blanc. Premiers résultats d'une enquête sur la mise en page dans le livre médiéval', in Questa, Cesare / Raffaelli, Renato (eds), Il libro e il testo. Atti del convegno internazionale (Urbino, settembre 1982), Urbino: QuattroVenti, 195-221 (repr. in [Ornato, Ezio et al.] [1997], La face cachée du livre médiéval. L'histoire du livre vue par Ezio Ornato, ses amis et ses collègues. Avec une préface d'Armando Petrucci, Roma: Viella [I libri di Viella, 10], 473-508).

Bozzolo, Carla / Coq, Dominique / Muzerelle, Denis / Ornato, Ezio (1987), 'Page savante, page vulgaire : étude comparative de la mise en page des livres en latin et en français écrits ou imprimés en France au XV siècle', in Baumgartner, Emmanuèle / Boulestreau, Nicole (eds), La présentation du livre. Actes du Colloque, Paris X-Nanterre (4, 5, 6 décembre 1985), Paris: Centre de recherches du Département de français de Paris X-Nanterre (Littérales, 2), 121-133 (repr. in [Ornato, Ezio et al.] [1997], La face cachée du livre médiéval. L'histoire du livre vue par Ezio Ornato, ses amis et ses collègues. Avec une préface d'Armando Petrucci, Roma: Viella [I libri di Viella, 10], 509-517).

Bühler, Curt Ferdinand (1946), 'The Margins in Mediaeval Books', in The Papers of the Bibliographical Society of America, 40: 32-42.

Bühler, Curt Ferdinand (1958), The University and the Press in fifteenth-Century Bologna, Notre Dame, Ind.: Mediaeval Institute (Texts and Studies in the History of Medieval Education).

*Busonero, Paola (1999), 'La fascicolazione del manoscritto nel basso medioevo', in Busonero, Paola / Casagrande Mazzoli, Maria Antonietta / Devoti, Luciana / Ornato, Ezio, La fabbrica del codice. Materiali per la storia del libro nel tardo medioevo, Roma: Viella (I libri di Viella, 14), 31-139.

Calasso, Francesco (1954), Medio Evo del diritto, I, Le fonti, Milano: Giuffrè.

Caprioli, Severino (1981), 'Convenzione su strato e apparato', in Studi senesi, 30: 417-424.

Chartularium Studii Bononiensis. Documenti per la storia dell'Università di Bologna dalle origini fino al secolo XV, 16 vols, Bologna: Commissione per la storia dell'Università di Bologna, 1909-1988.

Colli, Vincenzo (1990), 'Termini del diritto civile', in Weijers, Olga (ed.), Méthodes et instruments du travail intellectuel au Moyen Âge, Turnout: Brepols (Études sur le vocabulaire intellectuel du Moyen Âge, 3), 231-242.

Coq, Dominique / Ornato, Ezio (1987), 'Les séquences de composition du texte dans la typographie du XVe siècle. Une méthode quantitative d'identification', in Historie et mésure, 2/1: 87-136. 
Coq, Dominique / Ornato, Ezio (1988), 'La production et le marché des incunables. Le cas des livres juridiques', in Aquilon, Pierre / Martin, Henri-Jean (eds), Le livre dans l'Europe de la Renaissance. Actes du XXVIII colloque international d'Études humanistes de Tours, Paris: Promodis, 305-322 (repr. in [Ornato, Ezio et al.] [1997], La face cachée du livre médiéval. L'histoire du livre vue par Ezio Ornato, ses amis et ses collègues. Avec une préface d'Armando Petrucci, Roma: Viella [I libri di Viella, 10], 227-243).

Destrez, Jean (1935), La pecia dans les manuscrits universitaires du XIII et du XIVe siècle, Paris: Éditions Jacques Vautrain.

Devoti, Luciana (1994), 'Aspetti della produzione del libro a Bologna: il prezzo di copia del manoscritto giuridico tra XIII e XIV secolo', in Scrittura e Civiltà, 18: 77-142.

Devoti, Luciana / Tristano, Caterina (1998), 'Completus in textu et in glosis. Il libro giuridico a Bologna tra XIII e XIV secolo: il mercato dell'usato', in Nuovi Annali della Scuola Speciale per Archivisti e Bibliotecari, 12: 63-116.

Dolezalek, Gero Rudolf (1972), Verzeichnis der Handschiften zum römischen Recht bis 1600, Frankfurt am Main: Max-Planck-Institut für Europäische Rechtsgeschichte.

Dolezalek, Gero Rudolf (1985), Repertorium manuscriptorum veterum Codicis Iustiniani, I-II, Frankfurt a. M.: Klostermann (lus Commune Sonderhefte, 23).

Dolezalek, Gero Rudolf (1989), 'La pecia e la preparazione dei libri giuridici nei secoli XII-XIII', in Luoghi e metodi di insegnamento nell'Italia medioevale (secoli XII - XIV), Atti del convegno internazionale di studi, Lecce - Otranto 6-8 ottobre 1986, Lecce: Congedo editore, 201-217.

Dolezalek, Gero Rudolf (1994), 'Les gloses des manuscrits de droit: reflet des méthodes d'enseignement', in Hamesse, Jacqueline (ed.), Manuels, programmes de cours et techniques d'enseignement. Actes du Colloque international de Louvain-la-Neuve (9-11 septembre 1993), Louvain-la-Neuve: Institut d'études médiévales (Textes, études, congrès, 16), 235-255.

Febvre, Lucien / Martin, Henri-Jean (1985), La nascita del libro, Roma-Bari: Laterza (Universale Laterza, 154).

Fink-Errera, Guy (1983), 'La produzione dei libri di testo nelle Università medievali’, in Cavallo, Guglielmo (ed.), Libri e lettori nel medioevo. Guida storica e critica, Roma-Bari: Laterza (Universale Laterza, 419), 133-165.

Fransen, Gérard (1982), 'Les gloses des canonistes et des civilistes', in Bultot, Robert (ed.), Les genres littéraires dans les sources théologiques et philosophiques médiévales. Définition, critique et exploitation. Actes du colloque international de Louvain-la-Neuve, 25-27 mai 1981. Louvain-la-Neuve: Institut d'études médiévales (Textes, études, congrès, 5), 133-149.

Gumbert, Johan Peter (1993), 'Sizes and Formats', in Maniaci, Marilena / Munafò, Paola F. (eds), Ancient and Medieval Book Materials and Techniques (Erice, 18-25 September 1992), I-II, Città del Vaticano: Biblioteca Apostolica Vaticana (Studi e Testi, 357-358), I, 227-273.

Holtz, Louis (1995), 'Glosse e commenti', in Cavallo, Guglielmo / Leonardi, Claudio / Menestò, Ernesto (eds), Lo spazio letterario del Medioevo, 1. Il Medioevo latino, III. La ricezione del testo, Roma: Salerno, 59-111.

Kantorowicz, Hermann (1929), 'Accursio e la sua biblioteca', in Rivista di storia del diritto italiano, 2: $35-62$.

Lemaire, Jacques (1989), Introduction à la codicologie, Louvain-la-Neuve: Institut d'études médiévales (Textes, études, congrès, 9).

Lowry, Martin (1991), Nicholas Jenson and the Rise of Venetian Publishing in Renaissance Europe, Oxford: Blackwell. 
Maffei, Domenico (1975), 'Un trattato di Bonaccorso degli Elisei e i piu antichi statuti dello Studio di Bologna nel manoscritto 22 della Robbins Collection', in Bulletin of Medieval Canon Law, 5: 73-101.

Maniaci, Marilena (1996 [1998²]), Terminologia del libro manoscritto, Milano, Roma: Istituto centrale per la patologia del libro.

Maniaci, Marilena (1995), 'Ricette di costruzione della pagina nei manoscritti greci e latini', in Scriptorium, 49: 16-41.

Montecchi, Giorgio (1997 [1994]), 'Le dimensioni del libro secondo la Theorica et practica di Sigismondo Fanti', in Montecchi, Giorgio (ed.), Il libro nel Rinascimento, Roma: Viella (I libri di Viella, 11), 93-107 (1 $1^{\text {st }}$ edition, Milano: La storia, 1994).

Muzerelle, Denis (1985), Vocabulaire codicologique. Répertoire méthodique des termes français relatifs aux manuscrits, Paris: CEMI (Rubricae. Histoire du livre et des textes, 1).

Orlandelli, Gianfranco (1959), Il libro a Bologna dal 1300 al 1330 (documenti) con uno studio sul contratto di scrittura nella dottrina notarile bolognese, Bologna: Zanichelli.

Ornato, Ezio (1985), 'Les conditions de production et de diffusion du livre médiéval (XIII ${ }^{\mathrm{e}} \mathrm{XV}$ e siècles): quelques considérations générales', in Culture et idéologie dans la genèse de l'état moderne. Actes de la table ronde organisée par le Centre National de la Recherche Scientifique et l'Ecole Française de Rome, 15 - 17 octobre 1984, Rome: L'Ecole (Collection de l'École Française de Rome, 82), 57-84 (repr. in [Ornato, Ezio et al.] [1997], La face cachée du livre médiéval. L'histoire du livre vue par Ezio Ornato, ses amis et ses collègues. Avec une préface d'Armando Petrucci, Roma: Viella [I libri di Viella, 10], 97-116).

Ornato, Ezio (1991), 'La codicologie quantitative. outil privilégié de l'histoire du livre médiéval', in Historia, instituciones, documentos, 18, 375-402 (repr. in [Ornato, Ezio et al.] [1997], La face cachée du livre médiéval. L'histoire du livre vue par Ezio Ornato, ses amis et ses collègues. Avec une préface d'Armando Petrucci, Roma: Viella [I libri di Viella, 10], 41-65).

Ornato, Ezio (1994), 'Exigences fonctionnelles, contraintes matérielles et pratiques traditionnelles dans le livre médiéval : quelques réflexions', in Rück, Peter / Boghardt, Martin (eds), Rationalisierung der Buchherstellung im Mittelalter und in der frühen Neuzeit. Ergebnisse eines buchgeschichtlichen Seminars der Herzog August Bibliothek Wolfenbüttel (12-14 November 1990), Marburg: Institut für Historische Hilfswissenschaften, 7-31 (repr. in [Ornato, Ezio et al.] [1997], La face cachée du livre médiéval. L'histoire du livre vue par Ezio Ornato, ses amis et ses collègues. Avec une préface d'Armando Petrucci, Roma: Viella [I libri di Viella, 10], 117-159).

Parkes, Malcom (1976), 'The Influence of the Concepts of Ordinatio and Compilatio on the Development of the Book', in Alexander, Jonathan J. G. / Gibson, Margareth T. (eds), Medieval Learning and Literature: Essays Presented to Richard William Hunt, Oxford: Oxford University Press, 115-141.

Petrucci, Armando (1969), 'Alle origini del libro moderno. Libri da banco, libri da bisaccia, libretti da mano', in Italia medioevale e umanistica, 12: 295-313.

Petrucci, Armando (1983), 'Il libro manoscritto', in Asor Rosa, Alberto (ed.), Letteratura italiana, II, Produzione e consumo, Torino: Einaudi, 497-524.

Petrucci, Armando (1984), 'Lire au Moyen Âge', in Mélanges de l'Ecole française de Rome (Moyen Âge, temps modernes, 96), 603-616.

Pollard, Henry Graham (1978), 'The Pecia System in the Medieval Universities', in Parkes, Malcom / Watson, Andrew (eds), Medieval Scribes, Manuscripts and Libraries: Essays Presented to N. R. Ker, London: Scholar Press, 145-161. 
Powitz, Gerhardt (1979), 'Textus cum commento', in Codices manuscripti, 5, 80-89 (repr. in Powitz, Gerhardt [ed.] [2005], Handschriften und frühe Drucke: ausgewählte Aufsätze zur mittelalterlichen Buch- und Bibliotheksgeschichte, Frankfurt a. M.: Klostermann [Frankfurter Bibliotheksschriften, 12], 57-81).

Rambaud-Buhot, Jacqueline (1990), 'Le Décret de Gratien, in Martin, Henri-Jean / Vézin, Jean (eds), Mise en page et mise en texte du livre manuscrit, Paris: Éditions du Cercle de la Librairie - Promodis, 201-204.

Rambaud-Buhot, Jacqueline (1990a), 'Les Decretales', in Martin, Henri-Jean / Vézin, Jean (eds), Mise en page et mise en texte du livre manuscrit, Paris: Éditions du Cercle de la Librairie Promodis, 205-210.

Rizzo, Silvia (1973), Il lessico filologico degli umanisti, Roma: Edizioni di Storia e Letteratura (Sussidi eruditi, 26).

Rota, Andrea (1935), 'Un fondo giuridico ignorato dell'Archivio di Stato di Roma. I codici dell'Arcispedale del S.S. Salvatore ad Sancta Sanctorum', in Archivi, 2, 2: 155-177.

Saenger, Paul Henry (1982), Space Between Words: The Origins of Silent Reading, Stanford: Stanford University Press (Figurae. Reading Medieval Cultures).

Sella, Pietro (1932), Sigle di giuristi medievali, in inspecie dello Studio bolognese, tratte dai Codici vaticani, Bologna: Zanichelli (Biblioteca de l'Archiginnasio, 2/44).

Sella, Pietro (1935), Nuove sigle di giuristi medievali, Imola (Studi e Memorie per la Storia dell'Università di Bologna, 1).

Soetermeer, Frank (1989), 'L'ordre chronologique des apparatus d'Accurse sur les libri ordinarii', in Peláez, Manuel J. (ed.), Historia del derecho privado. Trabajos en homenaje a Ferran Valls $i$ Taberner, X, Barcelona: Promociones publicaciones universitarias (Serie bibliografica de derecho historico e historia de las instituciones), 2867-2892.

Soetermeer, Frank (1990), De pecia in juridische Handschriften, Utrecht: Elinkwijk.

Soetermeer, Frank (1997), Utrumque ius in peciis: aspetti della produzione libraria a Bologna fra Due e Trecento, Milano: Giuffrè (Orbis Academicus, 7).

Sorbelli, Albano (1929), Storia della stampa in Bologna, Bologna: Zanichelli.

Speciale, Giuseppe (1994), La memoria del diritto comune. Sulle tracce d'uso del Codex di Giustiniano (secoli XII-XV), Roma: II Cigno Galileo Galilei Edizioni di Arte e Scienza.

Stelling Michaud, Sven (1963), 'Le transport international des manuscrits juridiques bolonais entre 1265 et 1320', in Mélanges d'histoire économique et sociale en hommage au professeur Antony Babel, I, Genève: Imprimerie de la Tribune de Genève, 95-128.

Thilo, Ralf Michael (1984), 'Drucke des Corpus luris Civilis im deutschen Sprachraum', in Koppitz, Hans-Joachim (ed.), Gutenberg Jahrbuch, 59, Mainz: Selbstverlag der GutenbergGesellschaft, Internationale Vereinigung für Geschichte und Gegenwart der Druckkunst e. V., 52-66.

Tristano, Caterina (1991), 'Caratteristiche tecnico-formali dei codici dell'Italia meridionale tra IX e X secolo', in Vitolo, Giovanni / Mottola, Francesco (eds), Scrittura e produzione documentaria nel Mezzogiorno longobardo, [Cava dei Tirreni]: Badia (Acta Cavensia, 1), 55-89.

Tschichold, Jan (1965), 'Non-arbitrary Proportions of Page and Type Area', in Osley, Arthur Sidney (ed.), Calligraphy and Palaeography. Essays presented to Alfred Fairbank on his $70^{\text {th }}$ Birthday, London: Faber \& Faber, 179-191.

Weijers, Olga (1987), Terminologie des universités au XIII' siècle, Roma: Edizioni Dell'Ateneo (Lessico intellettuale europeo, 39). 